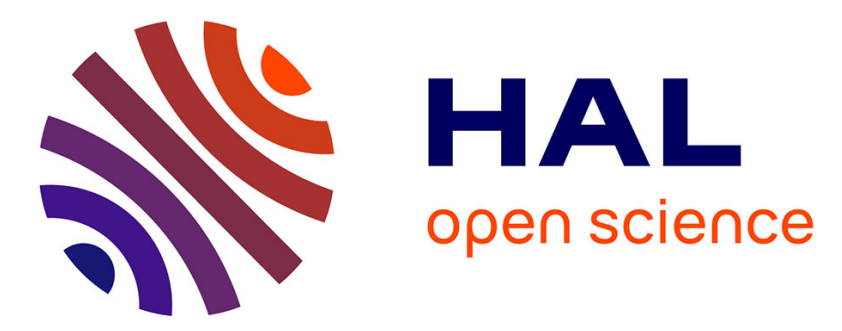

\title{
A versatile nitrogen ligand for alkaline-earth chemistry
}

Peter M. Chapple, Marie Cordier, Vincent Dorcet, Thierry Roisnel, Jean-François Carpentier, Yann Sarazin

\section{To cite this version:}

Peter M. Chapple, Marie Cordier, Vincent Dorcet, Thierry Roisnel, Jean-François Carpentier, et al.. A versatile nitrogen ligand for alkaline-earth chemistry. Dalton Transactions, 2020, 49 (34), pp.1187811889. 10.1039/d0dt02236e . hal-02930349

\section{HAL Id: hal-02930349 \\ https://hal.science/hal-02930349}

Submitted on 9 Nov 2020

HAL is a multi-disciplinary open access archive for the deposit and dissemination of scientific research documents, whether they are published or not. The documents may come from teaching and research institutions in France or abroad, or from public or private research centers.
L'archive ouverte pluridisciplinaire HAL, est destinée au dépôt et à la diffusion de documents scientifiques de niveau recherche, publiés ou non, émanant des établissements d'enseignement et de recherche français ou étrangers, des laboratoires publics ou privés. 


\title{
A versatile nitrogen ligand for alkaline-earth chemistry $\dagger$
}

\author{
Peter M. Chapple, ${ }^{a}$ Marie Cordier, ${ }^{\mathrm{b}}$ Vincent Dorcet, ${ }^{\mathrm{b}}$ Thierry Roisnel, ${ }^{\mathrm{b}}$
} Jean-François Carpentier ${ }^{\mathrm{a}}$ and Yann Sarazin ${ }^{\mathrm{a}, *}$

${ }^{a}$ Univ Rennes, CNRS, ISCR (Institut des Sciences Chimiques de Rennes) - UMR 6226, F-35000 Rennes, France.

${ }^{\mathrm{b}}$ Univ Rennes, CNRS, ISCR (Institut des Sciences Chimiques de Rennes) - CDFIX Diffraction Center, UMR 6226, F-35000 Rennes, France.

Corresponding author: yann.sarazin@univ-rennes1.fr

$\uparrow$ Electronic supplementary information (ESI) available: full experimental details including NMR spectra and crystallographic data for CCDC 2001221-2001225, 2003442, 20034444-2003446, 2004124-2004126 and 2009943 


\begin{abstract}
The tridentate ligand 1,8-bis-(2,6-diisopropylphenyl)imino-3,6-di-tert-butyl-carbazolate, $\left\{\mathrm{Carb}^{\mathrm{DiPP}}\right\}^{-}$, has been used to prepare a variety of complexes of the large alkaline earths (Ae) calcium, strontium and barium. A complex of their smaller congener, magnesium, has also been synthesised. The range of coligands that have been utilised include alkyls, amides, halides and tetrelides. All structurally characterised complexes presented herein are stable in solution and do not undergo ligand redistribution that is otherwise well-known to pollute the chemistry of the alkaline-earth metals. Detailed structural and spectroscopic data for these compounds are discussed. They provide compelling evidence that this nitrogen ligand allows for the kinetic stabilisation of Ae complexes through optimal steric encapsulation of the voluminous metal centres. Its ease of access combined to its evident versatility make $\left\{\mathrm{Carb}^{\mathrm{DiPP}}\right\} \mathrm{H}$ stand out in the portfolio of proligands that have been devised for similar purposes in the past decade. Yet, it fell short in our attempts to synthesise heteroleptic Ae-hydrides upon action of $\mathrm{PhSiH}_{3}$ onto Ae-amides, as the crystallised products showed the imine groups were prone to hydride reduction and formal hydrosilylation.
\end{abstract}




\section{Introduction}

Although it has long been overlooked, the molecular chemistry of the large alkaline earths (Ae) calcium, strontium and barium is now blossoming into a vibrant area. Thanks to the development of their fundamental organometallic chemistry, it has now become evident that these metals display a rich and original chemistry, vastly different from that of their smaller and more well-known congener, magnesium. ${ }^{1-16}$ Hence, rather than mere derivatives of Grignard reagents, well-defined, soluble complexes of the heavier Ae metals constitute suitable precursors for MOCVD applications ${ }^{1}$ and, perhaps more representatively, molecular catalysts and precatalysts for an array of metal-mediated organic reactions..$^{5-7,10-11,15}$ Besides, they also display exciting sub-catalytic reactivity towards small molecules that was hitherto unsuspected. ${ }^{10,17-26}$

These accomplishments have been made possible through a better understanding of the key principles that govern Ae chemistry. Calcium, strontium and barium are large, very electropositive metals that generate strongly ionic complexes, where weak bonding is primarily governed by electrostatic considerations (Fig. 1). These prominent features increase upon descending group 2, and to this day, the molecular coordination chemistry of barium has certainly proved difficult to assuage. One specific issue with Ae complexes is their propensity to undergo Schlenk equilibria in solution, a consequence of the ionic bonding in these divalent compounds. From a discrete heteroleptic complex [X-Ae-Y], this ligand-scrambling process forms homoleptic species $\left[\mathrm{AeX}_{2}\right]$ and $\left[\mathrm{AeY}_{2}\right]$. Although it may be useful in specific cases, e.g. for the quantitative preparation of magnesium dialkyls from Grignard reagents, it often produces mixtures that are unsuitable for catalysis. Like electropositivity and bond polarity, this disposition augments with $\mathrm{Mg}<\mathrm{Ca}<\mathrm{Sr}<\mathrm{Ba}$.

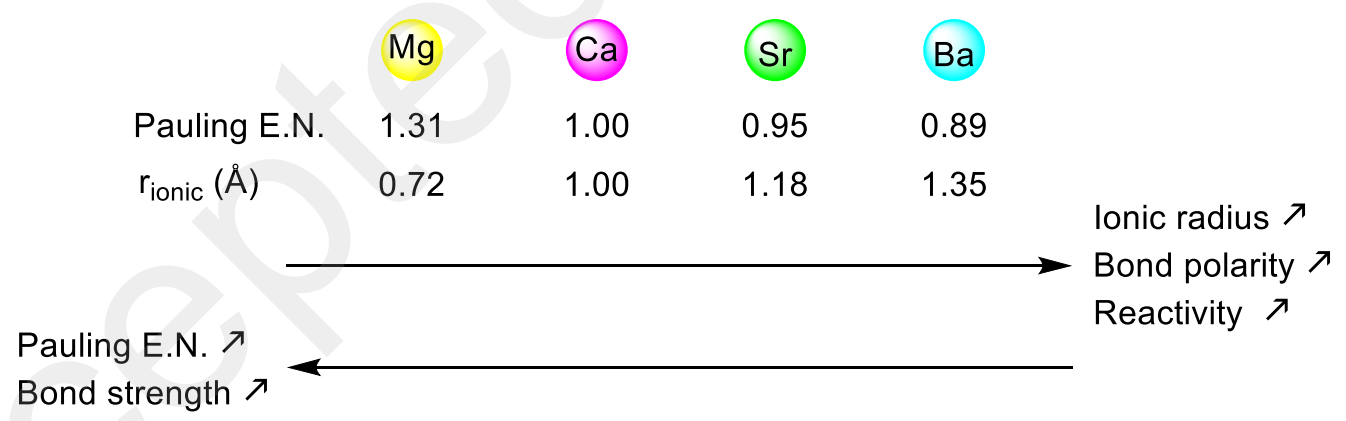

Figure 1. Trends in key physico-chemical features of the alkaline earths.

The design of kinetically stabilising bulky ligands has been instrumental in the developments of the molecular chemistry of $\mathrm{Ca}$, $\mathrm{Sr}$ and, to a less successful extent, $\mathrm{Ba}$. A number of monoanionic nitrogen-based ligands, e.g. amidinates and $\beta$-diketiminates, have been implemented. Amongst these, none has been more effective than the ubiquitous 2,6-bis-diisopropylphenyl- $\beta$-diketiminate (BDI ${ }^{\mathrm{DiPP}}$, Fig. 2; DiPP $=2$,6${ }^{i} \operatorname{Pr}_{2} \mathrm{C}_{6} \mathrm{H}_{3}$ ). This easily accessed ligand has been tremendously useful for calcium as well as magnesium and 
also, to some level, strontium. ${ }^{5,6,10,11,14,15,27,28}$. Since its introduction to alkaline-earth chemistry, ${ }^{29}$ e.g. to devise heteroleptic catalysts for the ring-opening polymerisation of cyclic esters, ${ }^{30}$ it has been the cornerstone for many of the breakthroughs in the field. Yet, for barium, it has not proved anywhere near as efficient, due to its inability to prevent ligand scrambling. For instance, [BDI ${ }^{\mathrm{DiPP}} \mathrm{BaN}\left(\mathrm{SiMe}_{3}\right)_{2} \cdot($ thf $)$ ] redistributes to $\left[\left(\mathrm{BDI}^{\mathrm{DiPP}}\right)_{2} \mathrm{Ba}\right]$ and $\left[\mathrm{Ba}\left\{\mathrm{N}\left(\mathrm{SiMe}_{3}\right)_{2}\right\}_{2} \cdot(\mathrm{thf})_{2}\right] .{ }^{31}$ The stabilisation of heteroleptic barium complexes is a well-known issue. ${ }^{10,14,32}$ Some other families of sterically congested multidentate ligands have been developed to address this specific problem (Fig. 2), such as the bulkier $\beta$-diketiminate BDI ${ }^{\text {DiPeP }} 33$ iminoanilides, ${ }^{34-36}$ dipyrromethene,${ }^{37}$ tris(pyrazolyl)borates, ${ }^{38}$ or also non-nitrogen ligands, e.g. substituted cyclopentadienyls ${ }^{39}$ and phenolates. ${ }^{40-41}$ They have met some success but, owing either to their tedious syntheses or insufficient stabilising properties, they have seldom been generalised to all three Ae metals. In fact, to date, no ligand has been shown to be equally efficacious at stabilising calcium, strontium and barium complexes.

We have recently reported on an easily accessed and bulky bis(imino)carbazolate ligand, Carb ${ }^{\text {DiPP }}$ (Fig. 2), that is particular effective at stabilising barium heteroleptic complexes. ${ }^{42}$ It has enabled the first syntheses of unusual species, such as soluble Ba-fluorides and Ba-stannyls. As a follow-up on these initial results, we are now showing that beyond barium, the practicality of this ligand framework extends across group 2 to the synthesis of stable calcium and strontium complexes. Its suitability for magnesium chemistry is also demonstrated. The preparation and the characterisation of a number of heteroleptic carbazolate Ae-halides, amides and alkyls are presented.
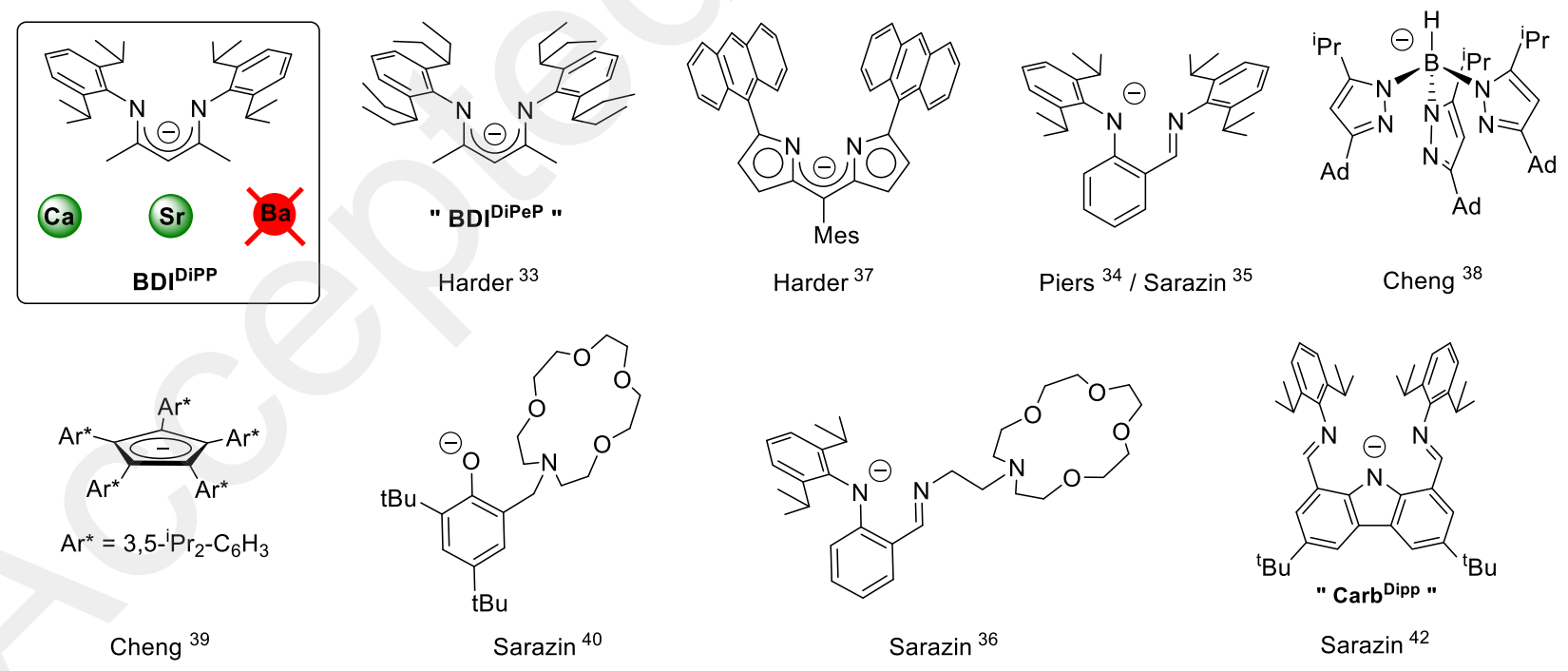

Figure 2. Selected ligands used to stabilise heteroleptic barium complexes. (Mes = mesityl, $\mathrm{Ad}=1$-adamantyl). 


\section{Results and Discussion}

The proligand 1,8-bis-(2,6-diisopropylphenyl)imino-3,6-di-tert-butyl-carbazole, designated as $\left\{\mathrm{Carb}^{\mathrm{DiPP}}\right\} \mathrm{H}$ hereafter, is readily available (70\% yield, $25 \mathrm{~g}$ scale) by condensation of 2,6-diisopropylaniline with 1,8diformyl-3,6-di-tert-butyl-carbazole. ${ }^{42}$ So far, it has been used to obtain a range of barium complexes which includes the unsolvated amide $\left[\left\{\mathrm{Carb}^{\mathrm{DiPP}}\right\} \mathrm{BaN}\left(\mathrm{SiMe}_{3}\right)_{2}\right](\mathbf{1})$, the halides $\left[\left(\left\{\mathrm{Carb}^{\mathrm{DiPP}}\right\} \mathrm{Ba}(\mu-\mathrm{F}) \cdot\right.\right.$ thf $_{2}(\mu$-thf $\left.)\right]$ (2) and $\left[\left\{\mathrm{Carb}^{\mathrm{DiPP}}\right\} \mathrm{BaI} \cdot(\mathrm{thf})_{2}\right](\mathbf{3})$; unique examples of Ba-tetrelides, [\{Carb $\left.{ }^{\mathrm{DiPP}}\right\} \mathrm{BaSi}\left(\mathrm{SiMe}_{3}\right)_{3} \cdot$ thf $](4)$ and $\left[\left\{\mathrm{Carb}^{\mathrm{DiPP}}\right\} \mathrm{BaSn}\left(\mathrm{SiMe}_{3}\right)_{3} \cdot\right.$ thf $](\mathbf{5})$ were also synthesised. Beyond these, we show here that $\left\{\mathrm{Carb}^{\mathrm{DiPP}}\right\} \mathrm{H}$ reacts in protonolysis reactions with a range of commonly available Ae-amides and alkyls such as $\mathrm{Mg}\left({ }^{n} \mathrm{Bu}\right)_{2}$ or the thf solvates $\left[\mathrm{Ae}\left\{\mathrm{N}\left(\mathrm{SiMe}_{3}\right)_{2}\right\}_{2} \cdot(\text { thf })_{2}\right]$ and $\left[\mathrm{Ae}\left\{\mathrm{CH}\left(\mathrm{SiMe}_{3}\right)_{2}\right\}_{2} \cdot(\text { thf })_{2}\right](\mathrm{Ae}=\mathrm{Ca} \mathrm{Sr}, \mathrm{Ba} ;$ Scheme 1).

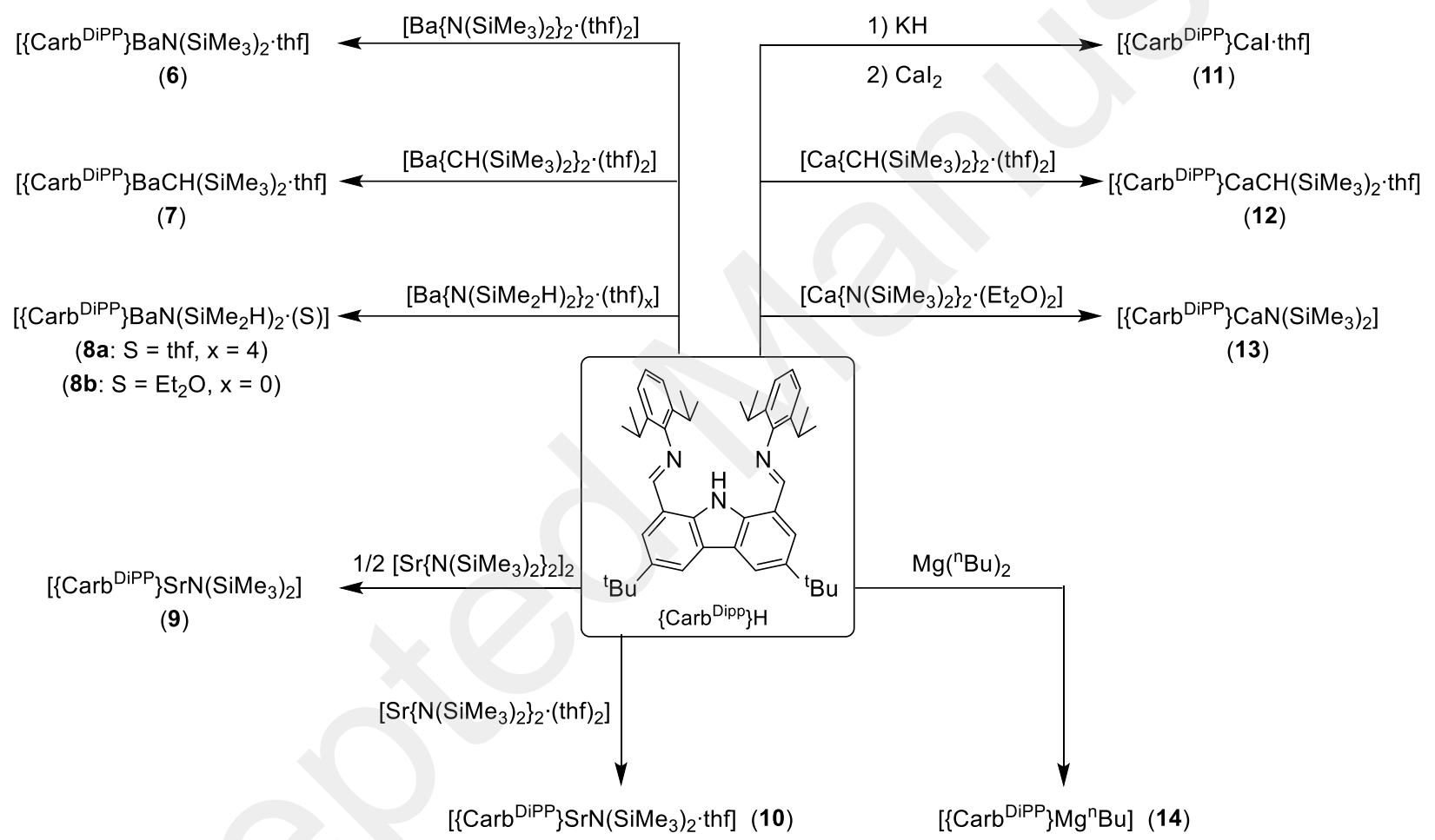

Scheme 1. Synthesis of barium, strontium, calcium and magnesium bis(imino)carbazolates 6-14.

\section{Barium complexes 6-8}

Beyond the reported complexes 1-5 that already illustrated its broad applicability in barium chemistry, ${ }^{42}$ $\left\{\mathrm{Carb}^{\mathrm{DiPP}}\right\} \mathrm{H}$ allows for the preparation of generally useful barium precursors. The thf-solvated Ba-amide [\{ $\left.\left.\mathrm{Carb}^{\mathrm{DiPP}}\right\} \mathrm{BaN}\left(\mathrm{SiMe}_{3}\right)_{2} \cdot \mathrm{thf}\right]$ (6) was isolated in good yield $(93 \%, 1.0 \mathrm{~g}$ scale) as a crop of bright yellow crystals following the treatment of the proligand with an equimolar amount of the convenient starting material $\left[\mathrm{Ba}\left\{\mathrm{N}\left(\mathrm{SiMe}_{3}\right)_{2}\right\}_{2} \cdot(\mathrm{thf})_{2}\right],{ }^{43}$ or from the addition of thf to $\mathbf{1}$. The presence of one molecule of coordinated thf per metal was established by NMR spectroscopy. For instance, the ${ }^{1} \mathrm{H}$ NMR spectrum of 6 recorded in toluene- $d_{8}$ at $25{ }^{\circ} \mathrm{C}$ features multiplets of expected intensities at 2.88 and $1.19 \mathrm{ppm}$ for $\alpha$ - and 
$\beta-\mathrm{CH}_{2}$ (thf) groups; another diagnostic resonance is that assigned to the imino $\mathrm{CH}=\mathrm{N}$ hydrogen atom, a singlet at $8.49 \mathrm{ppm}$. The ${ }^{13} \mathrm{C}\left\{{ }^{1} \mathrm{H}\right\}$ NMR spectrum of the complex is equally unequivocal. In a non-optimised process, crystals of the yellow Ba-alkyl complex $\left[\left\{\mathrm{Carb}^{\mathrm{DiPP}}\right\} \mathrm{BaCH}\left(\mathrm{SiMe}_{3}\right)_{2} \cdot \mathrm{thf}\right](7)$ were obtained in 69\% yield after the reaction in a J-Young NMR tube of $\left\{\mathrm{Carb}^{\mathrm{DiPP}}\right\} \mathrm{H}$ with Hill's precursor, $\left[\mathrm{Ba}\left\{\mathrm{CH}\left(\mathrm{SiMe}_{3}\right)_{2}\right\}_{2} \cdot(\text { thf })_{2}\right] .^{44-45} \mathrm{NMR}$ spectroscopy of 7 confirms the presence of a single molecule of coordinated THF; diagnostic resonances in the ${ }^{1} \mathrm{H}$ NMR spectrum included a high-field resonance at -1.84 ppm assigned to $\mathrm{CH}\left(\mathrm{SiMe}_{3}\right)_{3}$, and the deshielded one at $8.47 \mathrm{ppm}$ for $\mathrm{CH}=\mathrm{N}$. Complex 7 is one of the few discrete heteroleptic Ba-alkyls that have been structurally characterised to date (vide infra). Although 46 hits for compounds containing Ba-C bonds were identified in the CSD database, ${ }^{46}$ the few relevant examples are confined to the triazenide $\left[\left\{\mathrm{Ar}^{\prime} \mathrm{N}_{3} \mathrm{Ar}{ }^{\prime}{ }^{\prime}\right\} \mathrm{BaC}_{6} \mathrm{~F}_{5}\right]$ where $\mathrm{Ar}$ ' $=2,6-\mathrm{Mes}_{2}-\mathrm{C}_{6} \mathrm{H}_{3}$ and $\mathrm{Ar}{ }^{\prime \prime}=2-\left(2,4,6-{ }^{\mathrm{i}} \mathrm{Pr}_{3}-\right.$ $\left.\mathrm{C}_{6} \mathrm{H}_{2}\right)-\mathrm{C}_{6} \mathrm{H}_{4},{ }^{47}$ the highly congested Ba-cyclopentadienyl $\left[\left\{\mathrm{C}_{5} \mathrm{Ar}_{5}{ }_{5}\right\} \mathrm{BaCH}\left(\mathrm{SiMe}_{3}\right)_{2} \cdot(\text { thf })_{2}\right]$ where $\mathrm{Ar} *=3,5-$ ${ }^{i} \mathrm{Pr}_{2}-\mathrm{C}_{6} \mathrm{H}_{3},{ }^{39}$ and the iminoanilide [ $\left.\left\{2-(\mathrm{C}=\mathrm{N}-\mathrm{DiPP})-\mathrm{C}_{6} \mathrm{H}_{4}-\mathrm{N}-\mathrm{Dipp}\right\} \mathrm{BaCH}\left(\mathrm{SiMe}_{3}\right)_{2} \cdot(\text { thf })_{2}\right] .{ }^{48}$

The tetramethyldisilazide $\left[\left\{\mathrm{Carb}^{\mathrm{DiPP}}\right\} \mathrm{BaN}\left(\mathrm{SiMe}_{2} \mathrm{H}\right)_{2} \cdot \mathrm{thf}\right](\mathbf{8 a})$ and $\left[\left\{\mathrm{Carb}^{\mathrm{DiPP}}\right\} \mathrm{BaN}\left(\mathrm{SiMe}_{2} \mathrm{H}\right)_{2} \cdot \mathrm{Et}_{2} \mathrm{O}\right]$ (8b) were prepared from similar reactions between $\left\{\mathrm{Carb}^{\mathrm{DiPP}}\right\} \mathrm{H}$ and a slight excess of $\left[\mathrm{Ba}\left\{\mathrm{N}\left(\mathrm{SiMe}_{2} \mathrm{H}\right)_{2}\right\}_{2} \cdot(\text { thf })_{4}\right]$ for $\mathbf{8 a}$ and $\left[\mathrm{Ba}\left\{\mathrm{N}\left(\mathrm{SiMe}_{2} \mathrm{H}\right)_{2}\right\}_{2}\right]_{\mathrm{n}}$ for $\mathbf{8 b}$. Alternatively, 8a can be easily prepared by simply dissolving $\mathbf{8 b}$ in thf. The thf adduct $\mathbf{8 a}$ is a pale orange solid in the solid state, while the ether adduct $\mathbf{8 b}$ is a bright yellow colour. The tetramethyldisilazide $\mathrm{N}\left(\mathrm{SiMe}_{2} \mathrm{H}\right)_{2}{ }_{2}^{-}$has on occasions been employed in alkaline-earth chemistry (and elsewhere ${ }^{49-50}$ ) instead of the more routine hexamethyldisilazide $\mathrm{N}\left(\mathrm{SiMe}_{3}\right)_{2}{ }^{-}$ because it opens the possibility to set up favourable intramolecular $\beta-\mathrm{Si}-\mathrm{H}$ anagostic interactions that help stabilise electrophilic metal centres. ${ }^{40,51}$ All three complexes dissolve in ethers and toluene, but they are only sparingly to moderately soluble in aliphatic hydrocarbons and benzene.

XRD analysis of single-crystals of 6-8a shows that they generate five-coordinate monomers in the molecular solid state (Fig. 3, 4 and 5). Complex 6 forms a $C_{1}$-symmetric slightly distorted square pyramid $\left(\tau_{5}=0.13\right),{ }^{52}$ with the $\mathrm{N}_{\text {silazide }}$ atom (aka N4) occupying the apical position. At a distance of 1.1393(4) $\AA$, the barium atom is located well above the mean plane and basis of the square pyramid delineated by the four coplanar atoms N1, N2, N3 and O60. The interatomic distances to the $\mathrm{N}_{\text {imine }}$ atoms N1 and N3 (2.798(3) and 2.809(3) $\AA$ ) in $\mathbf{6}$ are substantially longer than in the four-coordinate congener $\left[\left\{\mathrm{Carb}^{\mathrm{DiPP}}\right\} \mathrm{BaN}\left(\mathrm{SiMe}_{3}\right)_{2}\right](\mathbf{1})$ (2.741(3) and 2.739(3) $\mathrm{A}) .{ }^{42}$ The Ba- $\mathrm{N}_{\text {silazide }}$ bond length is also somewhat longer in 6 (2.628(3) vs 2.585(4) $\AA$ ). On the other hand, the Ba- $\mathrm{N}_{\text {carbazolate }}$ distance in $\mathbf{6}$ (2.685(3) $\AA$ ) is slightly shorter than in $\mathbf{1}(2.722(3) \AA)$. Unsurprisingly, the presence of the additional coordinated thf molecule in 6 (Ba1-O60 $=2.780(3) \AA$ ) overall results in a weakening and elongation of the other Ba-heteroatom bonds.

The barium-alkyl 7, with its distorted square pyramidal geometry $\left(\tau_{5}=0.14\right)$, is isomorphous with the amido derivative 6. The alkyl group sits in apical position. The $\mathrm{Ba}-\mathrm{N}$ and $\mathrm{Ba}-\mathrm{O}$ interatomic distances are very similar in the two complexes. The $\mathrm{C}_{\text {alkyl }}$ atom (aka C11) is located 2.821(4) $\AA$ away from the metal 
centre, a distance matching that in [ $\left.\left\{2-(\mathrm{C}=\mathrm{N}-\mathrm{DiPP})-\mathrm{C}_{6} \mathrm{H}_{4}-\mathrm{N}-\mathrm{Dipp}\right\} \mathrm{BaCH}\left(\mathrm{SiMe}_{3}\right)_{2} \cdot(\text { thf })_{2}\right]\left(2.840(7) \AA^{48}\right)$ and $\left[\left\{\mathrm{C}_{5} \mathrm{Ar}_{5}\right\} \mathrm{BaCH}\left(\mathrm{SiMe}_{3}\right)_{2} \cdot(\text { thf })_{2}\right]\left(2.810(4) \AA^{39}\right)$.

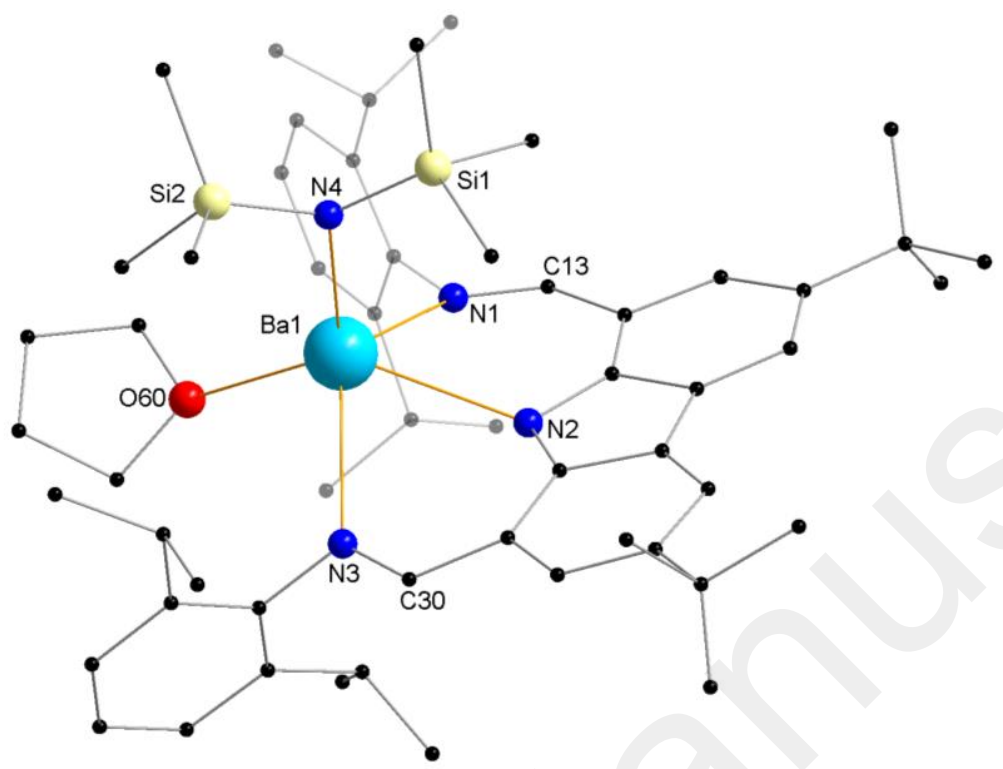

Figure 3. Molecular solid-state structure of $\left[\left\{\mathrm{Carb}^{\mathrm{DiPP}}\right\} \mathrm{BaN}\left(\mathrm{SiMe}_{3}\right)_{2} \cdot \mathrm{thf}\right](\mathbf{6}) . \mathrm{H}$ atoms omitted for clarity. Only the main components of the disordered ${ }^{\mathrm{B}} \mathrm{Bu}$ groups depicted. Selected interatomic distances $(\AA)$ and angles $\left({ }^{\circ}\right)$ : Ba1-N1 = 2.798(3), Ba1-N2 = 2.685(3), Ba1-N3 = 2.809(3), Ba1-N4 = 2.628(3), Ba1-O60 = 2.780(3); N1-Ba1-N2 = 69.97(8), N1-Ba1-N3 = 124.93(8), N1-Ba1-N4 = 114.31(9), N2-Ba1-N3 = 68.98(7), N2-Ba1-N4 = 103.87(8), N3-Ba1-N4 = 109.96(8), N1-Ba1-O60 = 87.10(7), N2-Ba1-O60 = 132.02(8), N3-Ba1-O60 = 94.21(7), N4-Ba1-O60 = 124.07(8).

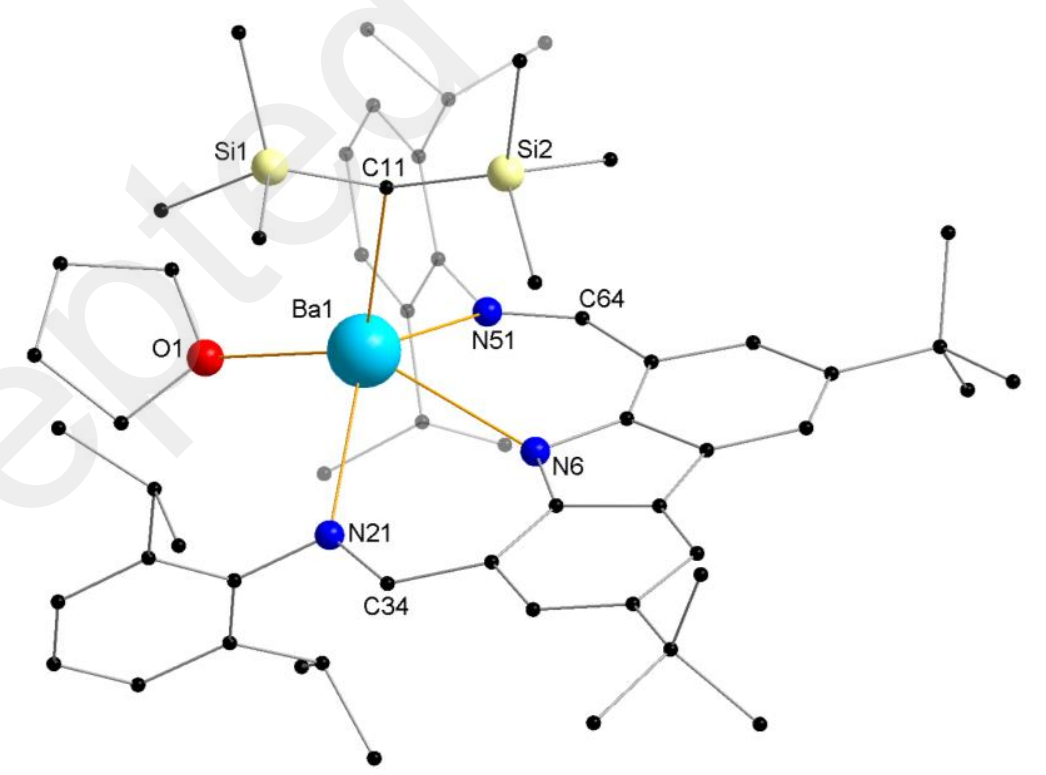

Figure 4. Representation of the molecular solid-state structure of [ $\left\{\mathrm{Carb}^{\mathrm{DiPP}}\right\} \mathrm{BaCH}\left(\mathrm{SiMe}_{3}\right)_{2} \cdot$ thf $](7)$. $\mathrm{H}$ atoms omitted for clarity. Only the main components of the disordered ${ }^{\mathrm{t}} \mathrm{Bu}$ groups depicted. Selected interatomic distances $(\AA)$ and angles $\left({ }^{\circ}\right)$ : Ba1-C11 $=2.821(4), \mathrm{Ba} 1-\mathrm{N} 6=2.672(3), \mathrm{Ba} 1-\mathrm{N} 21=2.774(3), \mathrm{Ba} 1-\mathrm{N} 51=2.801(3), \mathrm{Ba} 1-\mathrm{O} 1=2.741(3)$; C11-Ba1-N6 = 103.69(10), C11-Ba1-N21 = 116.04(10), C11-Ba1-N51 = 106.56(10), C11-Ba1-O1 = 120.18(10), N6Ba1-N21 = 69.63(8), N6-Ba1-N51 = 70.59(8), N6-Ba1-O1 = 135.31(8), N21-Ba1-N51 = 126.80(8), N21-Ba1-O1 = 96.24(9), N51-Ba1-O1 = 88.14(8). 


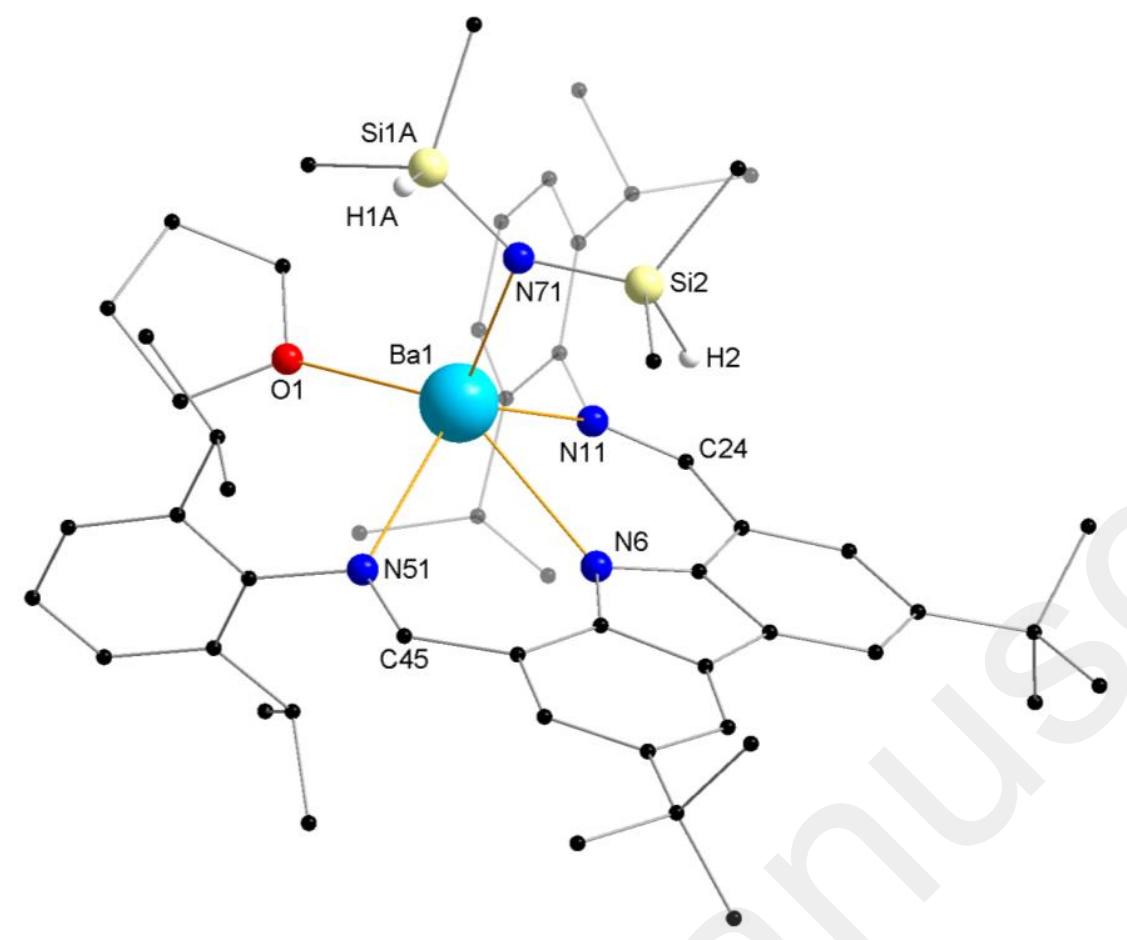

Figure 5. Representation of the molecular solid-state structure of $\left[\left\{\mathrm{Carb}^{\mathrm{DiPP}}\right\} \mathrm{BaN}\left(\mathrm{SiMe}_{2} \mathrm{H}\right)_{2} \cdot \mathrm{thf}\right](\mathbf{8 a}) . \mathrm{H}$ atoms other than $\mathrm{Si} H$ omitted for clarity. Only the main component of the disordered $\mathrm{SiMe}_{2} \mathrm{H}$ moiety at $\mathrm{Si} 1 \mathrm{~A}$ is depicted. Selected interatomic distances $(\AA)$ and angles $\left({ }^{\circ}\right)$ : Ba1-N6 $=2.6951(17)$, Ba1-N11 $=2.7744(19)$, Ba1-N51 $=2.7801(18)$, Ba1$\mathrm{N} 71=2.614(2), \mathrm{Ba} 1-\mathrm{O} 1=2.7599(19) ; \mathrm{N} 6-\mathrm{Ba} 1-\mathrm{N} 11=70.37(5), \mathrm{N} 6-\mathrm{Ba} 1-\mathrm{N} 51=68.75(5), \mathrm{N} 6-\mathrm{Ba} 1-\mathrm{N} 71$ = 104.70(7), N6-Ba1-O1 = 136.62(6), N11-Ba1-N51 = 126.60(5), N11-Ba1-N71 = 114.33(7), N11-Ba1-O1 = 90.44(6), N51-Ba1$\mathrm{N} 71=108.17(7), \mathrm{N} 51-\mathrm{Ba} 1-\mathrm{O} 1=96.43(6), \mathrm{N} 71-\mathrm{Ba} 1-\mathrm{O} 1=118.68(7) ; \mathrm{Ba} 1-\mathrm{N} 71-\mathrm{Si} 1 \mathrm{~A}=118.08(12), \mathrm{Ba} 1-\mathrm{N} 71-\mathrm{Si} 2=$ 108.58(12). Torsion angles $\left({ }^{\circ}\right)$ : Ba1-N71-Si1A-H1A = 104.65(12), Ba1-N71-Si2-H2 = 17.46(15).

The tetramethyldisilazide congener 8a also forms a distorted square pyramid (Fig. 5), with the silazide in apical position $\left(\tau_{5}=0.17\right)$. All Ba-heteroatom interatomic distances are commensurate with the equivalent ones in 6. At 2.614(2) $\AA$, the Ba1-N71 distance to the $\mathrm{N}_{\text {silazide }}$ atom is at the lowest end of the range for such bonds $;^{36,40,51}$ it is similar to that in the five-coordinate [ $\left.\left\{2-(\mathrm{C}=\mathrm{N}-\mathrm{DiPP})-\mathrm{C}_{6} \mathrm{H}_{4}-\mathrm{N}-\mathrm{Dipp}\right\} \mathrm{BaN}\left(\mathrm{SiMe}{ }_{2} \mathrm{H}\right)_{2} \cdot(\text { thf })_{2}\right]$ (2.601(4) $\AA$ ). ${ }^{53}$ The relatively small difference between the Ba1-N71-Si1A and Ba1-N71-Si2 angles $\left(118.08(12)^{\circ}\right.$ and $\left.108.58(12)^{\circ}\right)$, together with the torsion angles Ba1-N71-Si1A-H1A and Ba1-N71-Si2-H2 $\left(104.65(12)^{\circ}\right.$ and $\left.17.46(15)^{\circ}\right)$ both suggest that there is at best a single and mild $\mathrm{Ba} \cdots \mathrm{H}$-Si $\beta$-anagostic interaction involving the hydrogen atom $\mathrm{H} 2$. The ${ }^{1} \mathrm{H}$ NMR data displays a resonance for the Si-H hydrogen at $4.58 \mathrm{ppm}$, with a $\mathrm{Si}-\mathrm{H}$ coupling constant of $161 \mathrm{~Hz}$, indicative of only mild $\mathrm{Ba} \cdot \cdots \mathrm{H}-\mathrm{Si}$ interactions in solution. ${ }^{28}$ The FTIR spectrum recorded in Nujol displays two characteristic broad $\mathrm{Si}-\mathrm{H}$ stretching bands at 1998 and $1940 \mathrm{~cm}^{-1}$. The ether adduct $8 \mathbf{b}$ (see SI, Fig. S31) exhibits similar structural features to 8a, although it forms a very distorted square pyramid $\left(\tau_{5}=0.38\right)$. The Ba1-N1A distance of $2.587(4) \AA$ is slightly shorter than that of 8a, as expected with a weaker donor solvent. The ${ }^{1} \mathrm{H}$ NMR spectrum displays a resonance for 
the $\mathrm{Si}-\mathrm{H}$ hydrogen at $4.44 \mathrm{ppm}$, with almost identical $\mathrm{Si}-\mathrm{H}$ coupling constant as $8 \mathbf{a}$. The FTIR spectrum displays a broad band in at $2021 \mathrm{~cm}^{-1}$ attributed to the the $\mathrm{Si}-\mathrm{H}$ stretching frequency.

\section{Strontium complexes 9-10}

The proligand $\left\{\mathrm{Carb}^{\mathrm{DiPP}}\right\} \mathrm{H}$ allows for the formation of stable heteroleptic strontium amides. Reacting it in toluene with stoichiometric amounts of $\left[\mathrm{Sr}\left\{\mathrm{N}\left(\mathrm{SiMe}_{3}\right)_{2}\right\}_{2}\right]_{2}$ or $\left[\mathrm{Sr}\left\{\mathrm{N}\left(\mathrm{SiMe}_{3}\right)_{2}\right\}_{2} \cdot(\mathrm{thf})_{2}\right]$ affords $\left[\left\{\mathrm{Carb}^{\mathrm{DiPP}}\right\} \mathrm{SrN}\left(\mathrm{SiMe}_{3}\right)_{2}\right](\mathbf{9})$ and $\left[\left\{\mathrm{Carb}^{\mathrm{DiPP}}\right\} \mathrm{SrN}\left(\mathrm{SiMe}_{3}\right)_{2} \cdot \mathrm{thf}\right](\mathbf{1 0})$ as yellow solids in good isolated yields, typically around $60-65 \%$ without optimisation (see Scheme 1). The ${ }^{1} \mathrm{H}$ NMR spectrum of 9 recorded at $25{ }^{\circ} \mathrm{C}$ in benzene- $d_{6}$ is characterised in particular by a singlet at $8.53 \mathrm{ppm}$ assigned to $\mathrm{C} H=\mathrm{N}$, and a sharp, high-field singlet integrating for $18 \mathrm{H}$ at $-0.15 \mathrm{ppm}$ belonging to $\mathrm{SiCH}_{3}$ hydrogen atoms. The resonance for the $C \mathrm{H}=\mathrm{N}$ carbon atom of the imino group appears at $173.7 \mathrm{ppm}$ in the ${ }^{13} \mathrm{C}\left\{{ }^{1} \mathrm{H}\right\} \mathrm{NMR}$ spectrum of this complex. For the thf-adduct derivative 10, the corresponding resonances are visible at 8.60 and $-0.19 \mathrm{ppm}$ and at $174.1 \mathrm{ppm}$ in the ${ }^{1} \mathrm{H}$ and ${ }^{13} \mathrm{C}\left\{{ }^{1} \mathrm{H}\right\}$ NMR spectra in toluene- $d_{8}$, respectively. Hence, the additional coordination of the thf molecule in $\mathbf{1 0}$ does not induce substantial variations of the chemicals shifts, consistent for complexes where bonding is essentially ionic. Both complexes $\mathbf{9}$ and $\mathbf{1 0}$ are stable in solution at room temperature, although they exhibit slightly different solubility; 9 dissolves well in benzene and moderately so in hexanes, while $\mathbf{1 0}$ is only slightly soluble in benzene (although it is soluble in toluene). Note that complex $\mathbf{1 0}$ can be prepared upon dissolution of $\mathbf{9}$ in toluene containing a small amount of thf, followed by removal of the volatiles to constant weight.

The solvent-free 9 forms a monometallic four-coordinate complex with a slightly distorted trigonal pyramidal geometry in the molecular solid state $\left(\tau_{4}=0.65 ;{ }^{54}\right.$ Fig. 6$)$. The metal centre Sr1 is only $0.1046(3)$ $\AA$ above the plane defined by N1, N3 and N11. There is also considerable distortion in the ligand backbone, as the carbazolate core along with the imino fragments deviate clearly from the expected near planarity. ${ }^{42}$ The various $\mathrm{Sr}-\mathrm{N}$ interatomic distances in $\mathbf{9}$ are unremarkable; they are commensurate with those in related four-coordinate strontium complexes, e.g. $\left[\left\{\mathrm{BDI}^{\mathrm{DiPP}}\right\} \operatorname{SrN}\left(\mathrm{SiMe}_{3}\right)_{2} \cdot \mathrm{thf}{ }^{55}\left[\left\{\mathrm{BDI}^{\mathrm{DiPeP}}\right\} \operatorname{SrN}\left(\mathrm{SiMe}_{3}\right)_{2} \cdot \mathrm{thf}{ }^{33}\right.\right.$ and $\left[\left\{2-(\mathrm{C}=\mathrm{N}-\mathrm{DiPP})-\mathrm{C}_{6} \mathrm{H}_{4}-\mathrm{N}-\mathrm{Dipp}\right\} \operatorname{SrN}\left(\mathrm{SiMe}_{3}\right)_{2} \cdot\right.$ thf $] .{ }^{48}$ 


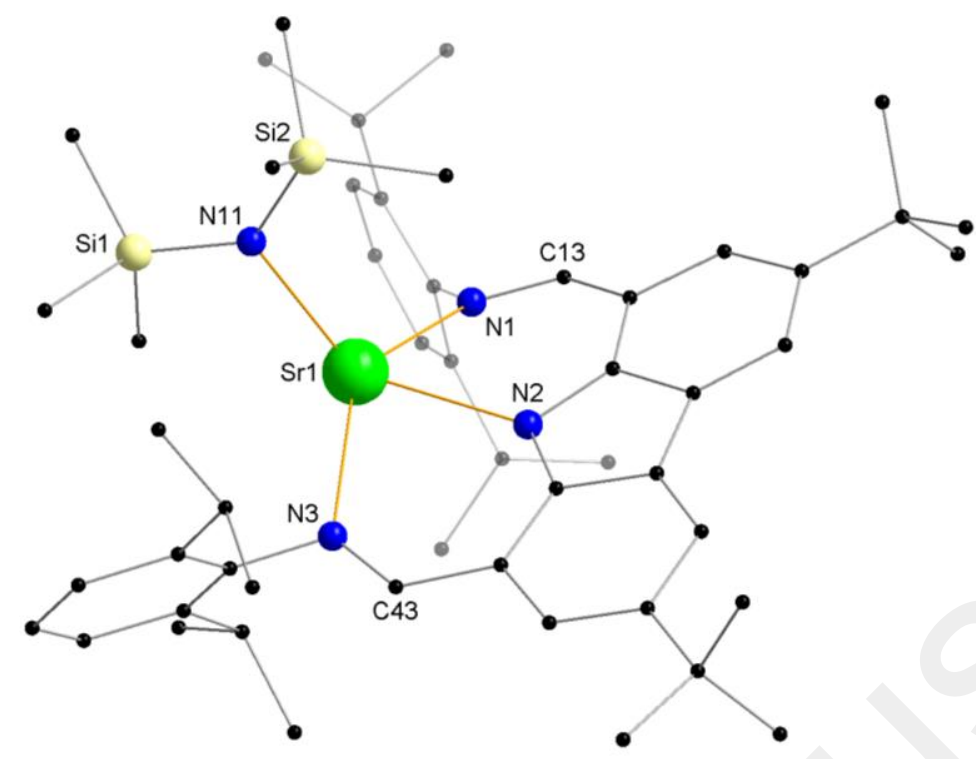

Figure 6. Representation of the molecular solid-state structure of $\left[\left\{\mathrm{Carb}^{\mathrm{DiPP}}\right\} \mathrm{SrN}\left(\mathrm{SiMe}_{3}\right)_{2}\right](9)$. $\mathrm{H}$ atoms and noninteracting hydrocarbon molecule omitted for clarity. Only the main component of the disordered 'Bu group depicted. Selected interatomic distances $(\AA)$ and angles $\left({ }^{\circ}\right)$ : Sr1-N1 $=2.6201(17), \operatorname{Sr} 1-\mathrm{N} 2=2.4941(18), \mathrm{Sr} 1-\mathrm{N} 3=2.6194(18)$, Sr1-N11 = 2.423(2); N1-Sr1-N2 = 74.74(5), N1-Sr1-N3 = 138.75(6), N1-Sr1-N11 = 111.46(7), N2-Sr1-N3 = 74.67(6), N2-Sr1-N11 = 129.52(7), N3-Sr1-N11 = 109.27(7).

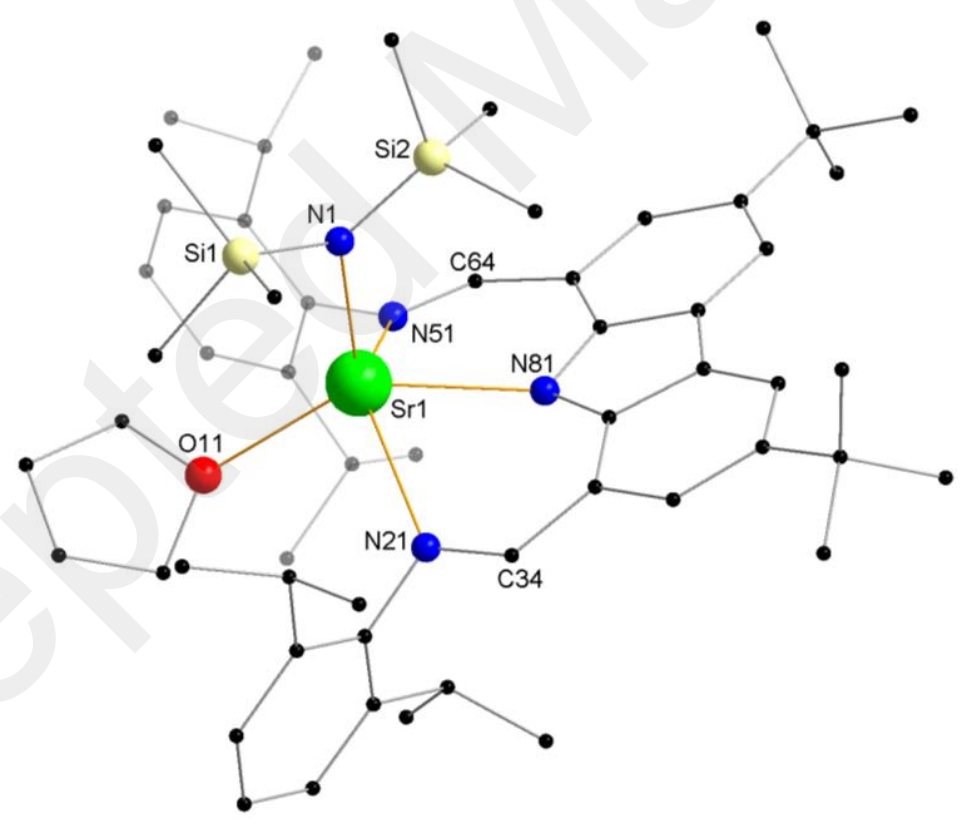

Figure 7. Representation of the molecular solid-state structure of $\left[\left\{\mathrm{Carb}^{\mathrm{DiPP}}\right\} \operatorname{SrN}\left(\mathrm{SiMe}_{3}\right)_{2} \cdot\right.$ thf $](\mathbf{1 0})$. $\mathrm{H}$ atoms omitted for clarity. Only the main components of the disordered 'Bu groups depicted. Selected interatomic distances $(\AA)$ and angles $\left({ }^{\circ}\right)$ : Sr1-N1 = 2.4939(19), Sr1-N21 = 2.6943(18), Sr1-N51 = 2.6774(19), Sr1-N81 = 2.5116(17), Sr1-O11 = 2.6230(17); N1-Sr1-N21 = 110.64(6), N1-Sr1-N51 = 111.02(6), N1-Sr1-N81 = 102.44(6), N1-Sr1-O11 = 121.69(6), N21-Sr1-N51 = 130.69(5), N21-Sr1-N81 = 72.40(5), N21-Sr1-O11 = 93.74(6), N51-Sr1-N81 = 73.92(6), N51-Sr1$\mathrm{O} 11=86.06(6), \mathrm{N} 81-\mathrm{Sr} 1-\mathrm{O} 11=135.71(6)$. 
Like its barium analogue 6, complex 10 forms an arrangement close to ideal square pyramidal $\left(\tau_{5}=\right.$ 0.08) with the silazide in apical position (Fig. 7). The two complexes are isostructural. Compared to the non-solvated 9, the presence of metal-bound thf results in the elongation of the Sr-N bonds in 10. The strontium atom is 1.0032(4) $\AA$ above the best average plane defined by the four heteroatoms at the basis of the square pyramidal arrangement, O11-N21-N51-N81.

\section{Calcium complexes 11-13}

The bright yellow calcium iodide $\left[\left\{\mathrm{Carb}^{\mathrm{DiPP}}\right\} \mathrm{CaI} \cdot \mathrm{thf}\right](\mathbf{1 1})$ was prepared in $78 \%$ yield by reaction of $\left[\left\{\mathrm{Carb}^{\mathrm{DiPP}}\right\} \mathrm{K} \cdot(\mathrm{thf})_{2}\right]^{42}$ with $\mathrm{CaI}_{2}$ in thf. The reaction is slightly sluggish, requiring heating to $50{ }^{\circ} \mathrm{C}$ to drive it to completion overnight. This complex constitutes a useful starting material for the synthesis of other calcium compounds via salt metathesis (vide infra), related to the disolvated barium-iodide $\left[\left\{\mathrm{Carb}^{\mathrm{DiPP}}\right\} \mathrm{BaI} \cdot(\text { thf })_{2}\right](3)$. It forms a five-coordinate monomer in the molecular solid-state (Fig. 8), where the iodide sits at the apex of a distorted square pyramidal geometry $\left(\tau_{5}=0.17\right)$. It is one of the few fivecoordinate monomeric Ca-iodides (the lowest coordination number known for such species) that have been structurally authenticated; most form iodide-bridged di- or multimetallic species. ${ }^{46}$ Hence, the Ca1-I1 interatomic distance in $\mathbf{1 1}(2.9702(8) \AA)$ is shorter than in the tris(imidazolin-2-ylidene-1-yl)borate $\left[\left\{\mathrm{HB}\left(\mathrm{Im}^{\mathrm{t}} \mathrm{Bu}\right)_{3}\right\} \mathrm{CaI} \cdot \mathrm{thf}\right](3.0490(9) \AA),{ }^{56}$ or in $\left[\left\{2,6-(4-\text { tol })_{2} \mathrm{C}_{6} \mathrm{H}_{3}\right\} \mathrm{CaI} \cdot(\text { thf })_{3}\right](3.0754(7) \AA),{ }^{57}$ suggesting a stronger bond in the former.

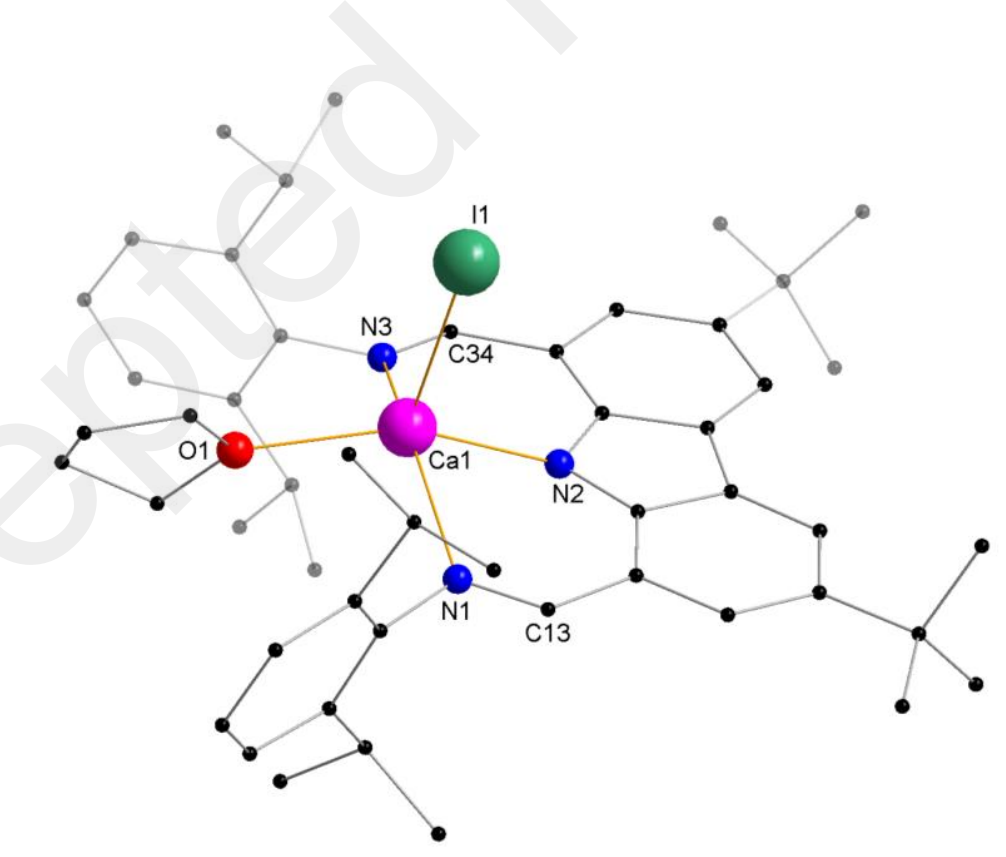

Figure 8. Representation of the molecular solid-state structure of $\left[\left\{\mathrm{Carb}^{\mathrm{DiPP}}\right\} \mathrm{CaI} \cdot \mathrm{thf}\right](\mathbf{1 1}) . \mathrm{H}$ atoms and non-interacting benzene molecules omitted for clarity. Selected interatomic distances $(\AA)$ and angles $\left({ }^{\circ}\right)$ : Ca1-I1 $=2.9702(8)$, Ca1-N1 $=2.479(3), \mathrm{Ca} 1-\mathrm{N} 2=2.317(3), \mathrm{Ca} 1-\mathrm{N} 3=2.471(3), \mathrm{Ca} 1-\mathrm{O} 1=2.365(3) ; \mathrm{I} 1-\mathrm{Ca} 1-\mathrm{N} 1=102.87(7), \mathrm{I} 1-\mathrm{Ca} 1-\mathrm{N} 2=$ 100.72(7), I1-Ca1-N3 = 108.37(7), I1-Ca1-O1 = 104.33(8), N1-Ca1-N2 = 79.11(10), N1-Ca1-N3 = 144.44(10), N1Ca1-O1 = 93.97(11), N2-Ca1-N3 = 78.80(10), N2-Ca1-O1 = 154.91(11), N3-Ca1-O1 = 94.36(10). 
The alkyl complex $\left[\left\{\mathrm{Carb}^{\mathrm{DiPP}}\right\} \mathrm{CaCH}\left(\mathrm{SiMe}_{3}\right)_{2} \cdot \mathrm{thf}\right](\mathbf{1 2})$ and the solvent-free $\left[\left\{\mathrm{Carb}^{\mathrm{DiPP}}\right\} \mathrm{CaN}\left(\mathrm{SiMe}_{3}\right)_{2}\right]$ amide (13) were obtained in 80-90\% yields as yellow crystals following protonolysis between $\left\{\mathrm{Carb}^{\mathrm{DiPP}}\right\} \mathrm{H}$ and $\left[\mathrm{Ca}\left\{\mathrm{CH}\left(\mathrm{SiMe}_{3}\right)_{2}\right\}_{2} \cdot(\text { thf })_{2}\right]$ or $\left[\mathrm{Ca}\left\{\mathrm{N}\left(\mathrm{SiMe}_{3}\right)_{2}\right\}_{2} \cdot\left(\mathrm{Et}_{2} \mathrm{O}\right)_{2}\right]$ (see Scheme 1). The resonance for $\mathrm{SiCH}_{3}$ hydrogen atoms appears at $-0.22 \mathrm{ppm}$ in the ${ }^{1} \mathrm{H}$ NMR spectrum of $\mathbf{1 3}$; that for $\mathrm{CH}\left(\mathrm{SiMe}_{3}\right)_{2}$ is located at $1.75 \mathrm{ppm}$ in the spectrum of $\mathbf{1 2}$. While $\mathbf{1 3}$ is stable in solution, $\mathbf{1 2}$ decomposes slowly above $50{ }^{\circ} \mathrm{C}$, via assumed alkylation of the imine by $\left\{\mathrm{CH}\left(\mathrm{SiMe}_{3}\right)_{2}\right\}^{-}$(see Fig. S29) The molecular structure of the fivecoordinate calcium alkyl 12 is depicted in Fig. 9. It consists of a distorted square pyramid $\left(\tau_{5}=0.13\right)$ that resembles very closely the structure of the barium derivative, 7. The metal atom Ca1 is situated 0.7988(5) $\AA$ above the best average plane defined by O1, N6, N21 and N51. The Ca1-C11 distance to the alkyl in 12 $(2.539(3) \AA)$ is appreciably longer than in $\left[\mathrm{Ca}\left\{\mathrm{CH}\left(\mathrm{SiMe}_{3}\right)_{2}\right\}_{2} \cdot(\mathrm{thf})_{2}\right]\left(2.4930(18) \AA^{44}\right)$ and in the tris(pyrazolyl)borate $\left[\left\{\mathrm{Tp}^{\mathrm{Ad}, \mathrm{iPr}}\right\} \mathrm{CaCH}\left(\mathrm{SiMe}_{3}\right)_{2}\right]\left(2.4409(86) \AA^{38}\right)$, both being four-coordinate compounds; surprisingly, there is no available example of five-coordinate $[\mathrm{Ca}]-\mathrm{CH}\left(\mathrm{SiMe}_{3}\right)_{2}$ in the CSD database. ${ }^{46}$ The geometry about the calcium atom in the four-coordinate $\mathbf{1 3}$ approximates a trigonal pyramidal configuration $\left(\tau_{4}=0.58\right)$, where Ca1 is actually located in the plane defined by N1, N11 and N31 (Fig. 10).

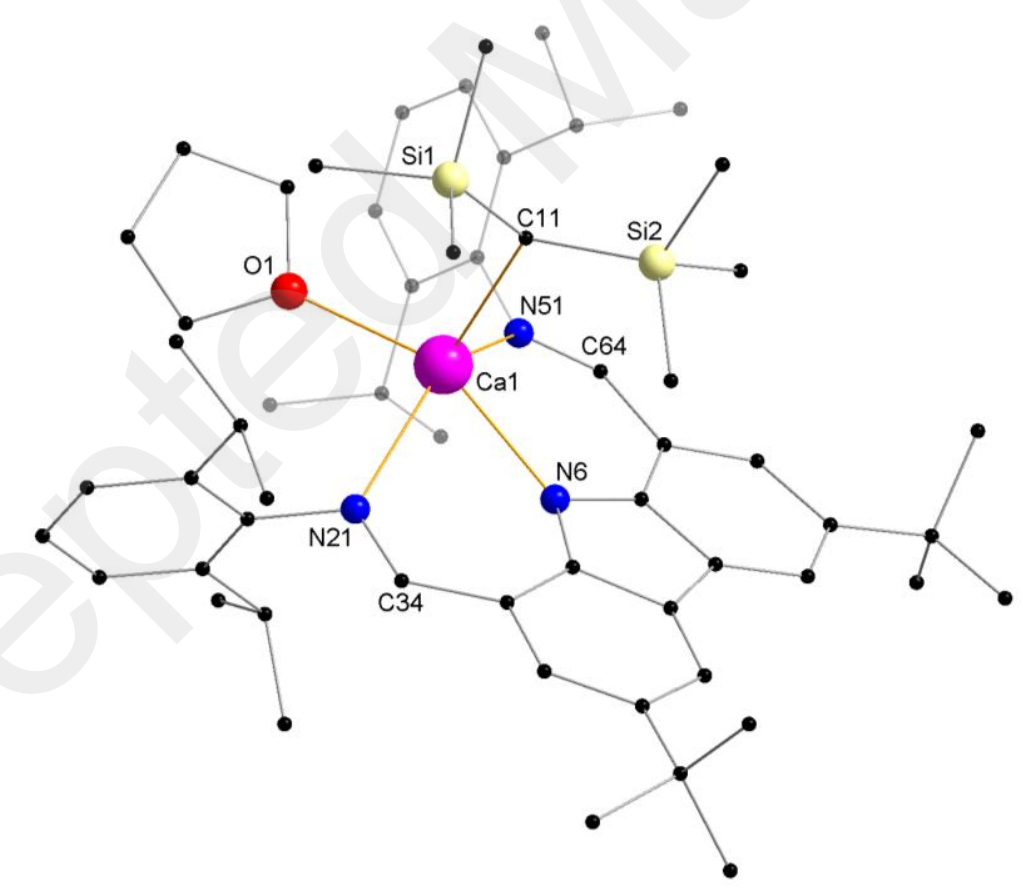

Figure 9. Representation of the molecular solid-state structure of $\left[\left\{\mathrm{Carb}^{\mathrm{DiPP}}\right\} \mathrm{CaCH}\left(\mathrm{SiMe}_{3}\right)_{2} \cdot\right.$ thf $](\mathbf{1 2})$. $\mathrm{H}$ atoms omitted for clarity. Only the main components of the disordered ${ }^{\mathrm{B}} \mathrm{Bu}$ groups depicted. Selected interatomic distances $(\AA)$ and angles $\left({ }^{\circ}\right)$ : Ca1-C11 = 2.539(3), Ca1-N6 = 2.353(2), Ca1-N21 = 2.569(2), Ca1-N51 = 2.594(2), Ca1-O1 = 2.426(2); C11-Ca1-N6 = 107.26(9), C11-Ca1-N21 = 114.59(8), C11-Ca1-N51 = 105.49(9), C11-Ca1-O1 = 107.43(8), N6-Ca1$\mathrm{N} 21=76.38(7), \mathrm{N} 6-\mathrm{Ca} 1-\mathrm{N} 51=77.63(7), \mathrm{N} 6-\mathrm{Ca} 1-\mathrm{O} 1=144.85(8), \mathrm{N} 21-\mathrm{Ca} 1-\mathrm{N} 51=137.04(7), \mathrm{N} 21-\mathrm{Ca} 1-\mathrm{O} 1=$ 94.17(7), N51-Ca1-O1 = 87.89(7). 


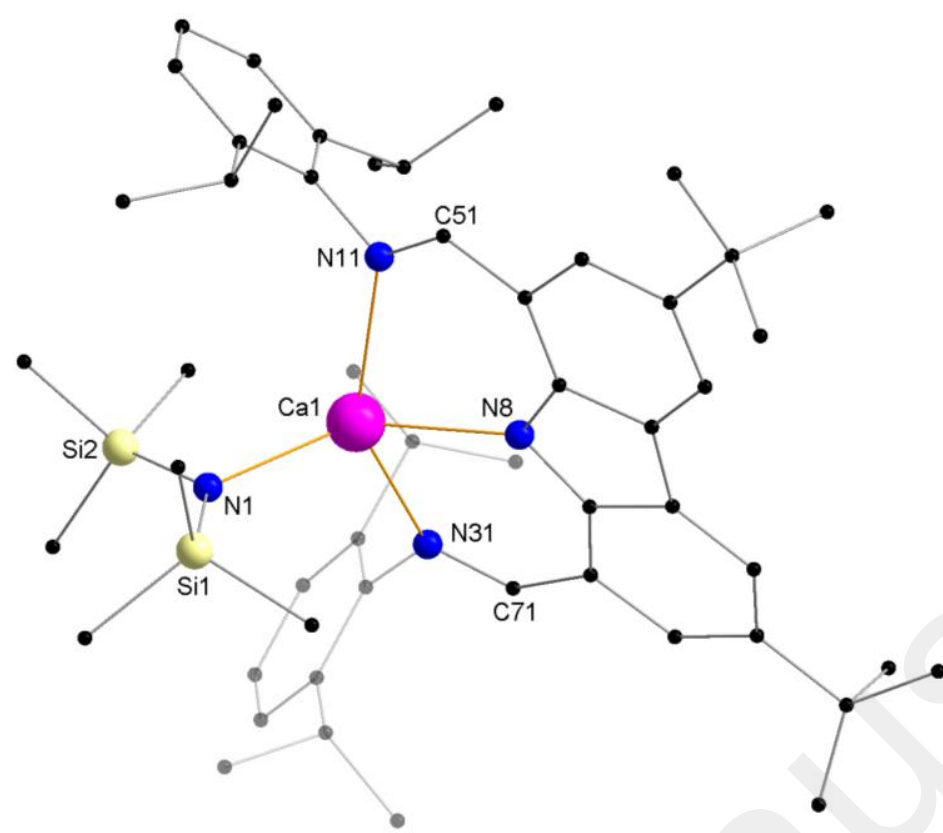

Figure 10. Representation of the molecular solid-state structure of $\left[\left\{\mathrm{Carb}^{\mathrm{DiPP}}\right\} \mathrm{CaN}\left(\mathrm{SiMe}_{3}\right)_{2}\right](\mathbf{1 3}) . \mathrm{H}$ atoms omitted for clarity. Only the main component of the disordered ${ }^{\mathrm{t}} \mathrm{Bu}$ group depicted. Selected interatomic distances $(\AA)$ and angles $\left({ }^{\circ}\right.$ ): $\mathrm{Ca} 1-\mathrm{N} 1=2.2808(14), \mathrm{Ca} 1-\mathrm{N} 8=2.3403(13), \mathrm{Ca} 1-\mathrm{N} 11=2.5128(13), \mathrm{Ca} 1-\mathrm{N} 31=2.5154(14) ; \mathrm{N} 1-\mathrm{Ca} 1-\mathrm{N} 8$ $=132.49(5), \mathrm{N} 1-\mathrm{Ca} 1-\mathrm{N} 11=107.55(5), \mathrm{N} 1-\mathrm{Ca} 1-\mathrm{N} 31=106.89(5), \mathrm{N} 8-\mathrm{Ca} 1-\mathrm{N} 11=77.87(4), \mathrm{N} 8-\mathrm{Ca} 1-\mathrm{N} 31=79.86(4)$, N11-Ca1-N31 = 145.54(5).

\section{Magnesium complex 14}

Finally, the ability of the bis(imino)carbazolate ligand $\left\{\mathrm{Carb}^{\mathrm{DiPP}}\right\}^{-}$to stabilise magnesium complexes was confirmed upon reaction of the proligand with $\left[\mathrm{Mg}\left({ }^{\mathrm{n}} \mathrm{Bu}\right)_{2}\right]$. The reaction, carried out in hexanes, readily afforded [ $\left.\left\{\mathrm{Carb}^{\mathrm{DiPP}}\right\} \mathrm{Mg}^{\mathrm{n}} \mathrm{Bu}\right](\mathbf{1 4})$ as a yellow-orange powder in $91 \%$ yield. Diagnostic resonances in the ${ }^{1} \mathrm{H}$ NMR spectrum of 14 include a singlet at $8.36 \mathrm{ppm}$ for the $\mathrm{CH}=\mathrm{N}$ hydrogen atom, and a high-field multiplet at $-0.36 \mathrm{ppm}$ assigned to $\mathrm{MgCH}_{2}$ hydrogens. Its molecular solid-state structure (Fig. 11) shows the fourcoordinate complex to exist as a flattened trigonal pyramid $\left(\tau_{4}=0.43\right)$, where $\operatorname{Mg} 1$ sits $0.6044(8) \AA$ above the N1-N2-N3 plane while the angle C47A-Mg1-N2 is very wide $\left(150.5(2)^{\circ}\right)$. The $\mathrm{Mg} 1-\mathrm{N} 2$ and $\mathrm{Mg}-\mathrm{C} 47 \mathrm{~A}$ bond lengths (2.029(2) and 2.086(12) $\AA$ ) to the $\mathrm{N}_{\text {carbazolate }}$ and $\mathrm{C}_{\text {alkyl }}$ atoms in $\mathbf{1 4}$ are unexceptional. They compare well with to those in $\left[\left\{2,4,7,9-{ }^{t} \mathrm{Bu}_{4}-\mathrm{C}_{12} \mathrm{H}_{4} \mathrm{~N}\right\} \mathrm{MgEt} \cdot(\text { thf })_{2}\right]\left(2.087(3)\right.$ and 2.141(4) $\AA$ ). ${ }^{58}$ 


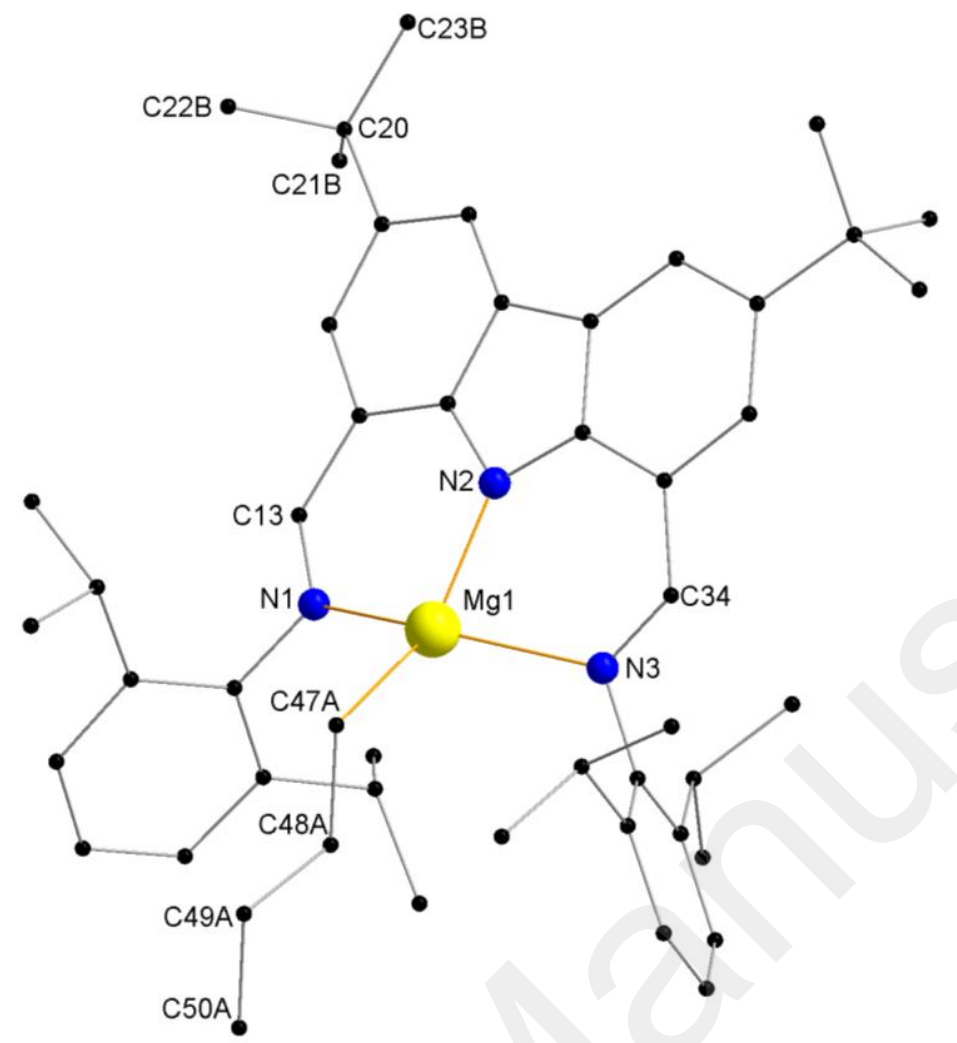

Figure 11. Representation of the molecular solid-state structure of $\left[\left\{\mathrm{Carb}^{\mathrm{DiPP}}\right\} \mathrm{Mg}^{\mathrm{n}} \mathrm{Bu}\right](\mathbf{1 4}) . \mathrm{H}$ atoms omitted for clarity. Only the main components of the disordered $n$-butyl (76\% occupation site at C47A) and $t$-butyl (at C20) groups depicted. Selected interatomic distances $(\AA)$ and angles $\left(^{\circ}\right): \operatorname{Mg} 1-\mathrm{N} 1=2.256(2), \mathrm{Mg} 1-\mathrm{N} 2=2.029(2), \mathrm{Mg} 1-\mathrm{N} 3=$ 2.249(2), Mg1-C47A = 2.086(12); N1-Mg1-N2 = 86.13(8), N1-Mg1-N3 = 148.87(8), N1-Mg1-C47A = 98.4(3), N2$\mathrm{Mg} 1-\mathrm{N} 3=85.09(8), \mathrm{N} 2-\mathrm{Mg} 1-\mathrm{C} 47 \mathrm{~A}=150.5(2), \mathrm{N} 3-\mathrm{Mg} 1-\mathrm{C} 47 \mathrm{~A}=103.9(3)$.

\section{Further reactivity}

Alkaline-earth hydrides have proved extremely valuable as soluble catalysts for hydrogenation reactions, as well as suspected or established in-cycle catalytically active species in a wealth or organic reactions such as hydroelementations and dehydrocouplings. ${ }^{15}$ Whereas magnesium ${ }^{59}$ and, to a lesser extent, calcium ${ }^{60-61}$ hydrides have been known for some time, it is only recently that the first well-defined strontium ${ }^{62-63}$ and barium $^{38,39,64}$ hydrides were unveiled. An effective route to these compounds has consisted in reacting discrete $[\mathrm{Ae}]-\mathrm{N}\left(\mathrm{SiMe}_{3}\right]_{2}$ silazides with hydrosilanes, typically $\mathrm{PhSiH}_{3}$. This has for instance delivered $\left[\left\{\mathrm{BDI}^{\mathrm{DiPP}}\right\} \mathrm{CaH} \cdot \mathrm{thf}\right]_{2}$ as well as the clusters $\left[\mathrm{Sr}_{6} \mathrm{H}_{9}\left\{\mathrm{~N}\left(\mathrm{SiMe}_{3}\right)_{2}\right\}_{3} \cdot(\text { pmdeta })_{3}\right]$ (where pmdeta = $N, N, N$, $N$ ', $N$ ','-pentamethyldiethylenetriamine) and $\left[\mathrm{Ba}_{7} \mathrm{H}_{7}\left\{\mathrm{~N}\left(\mathrm{SiMe}_{3}\right)_{2}\right\}_{7}\right] \cdot{ }^{60,62,64}$

Hence, in an attempt to generate a barium hydride supported by the $\left\{\mathrm{Carb}^{\mathrm{DiPP}}\right\}^{-}$framework, the barium amide 6 was reacted with a two-fold excess of $\mathrm{PhSiH}_{3}$. Yet, instead of the sought "[Carb $\left.\left.{ }^{\mathrm{DiPP}}\right\} \mathrm{BaH} \cdot(\text { thf })_{\mathrm{x}}\right]$ ", a crop of bright yellow crystals of the bimetallic complex $\left[\mathrm{Ba}_{2}\left\{\mathrm{Carb}^{\mathrm{DiPP} \text {, red }}\right\}\left\{\mathrm{Carb}^{\mathrm{DiPP} \text {,silyl }}\right\} \cdot(\text { thf })_{2}\right](\mathbf{1 5})$ was isolated in $30 \%$ yield, where $\left\{\mathrm{Carb}^{\text {DiPP,red }}\right\}^{3-}$ and $\left\{\mathrm{Carb}^{\text {DiPP,silyl }}\right\}^{-}$correspond respectively to formally reduced and hydrosilylated derivatives of the regular ligand (Scheme 2). 


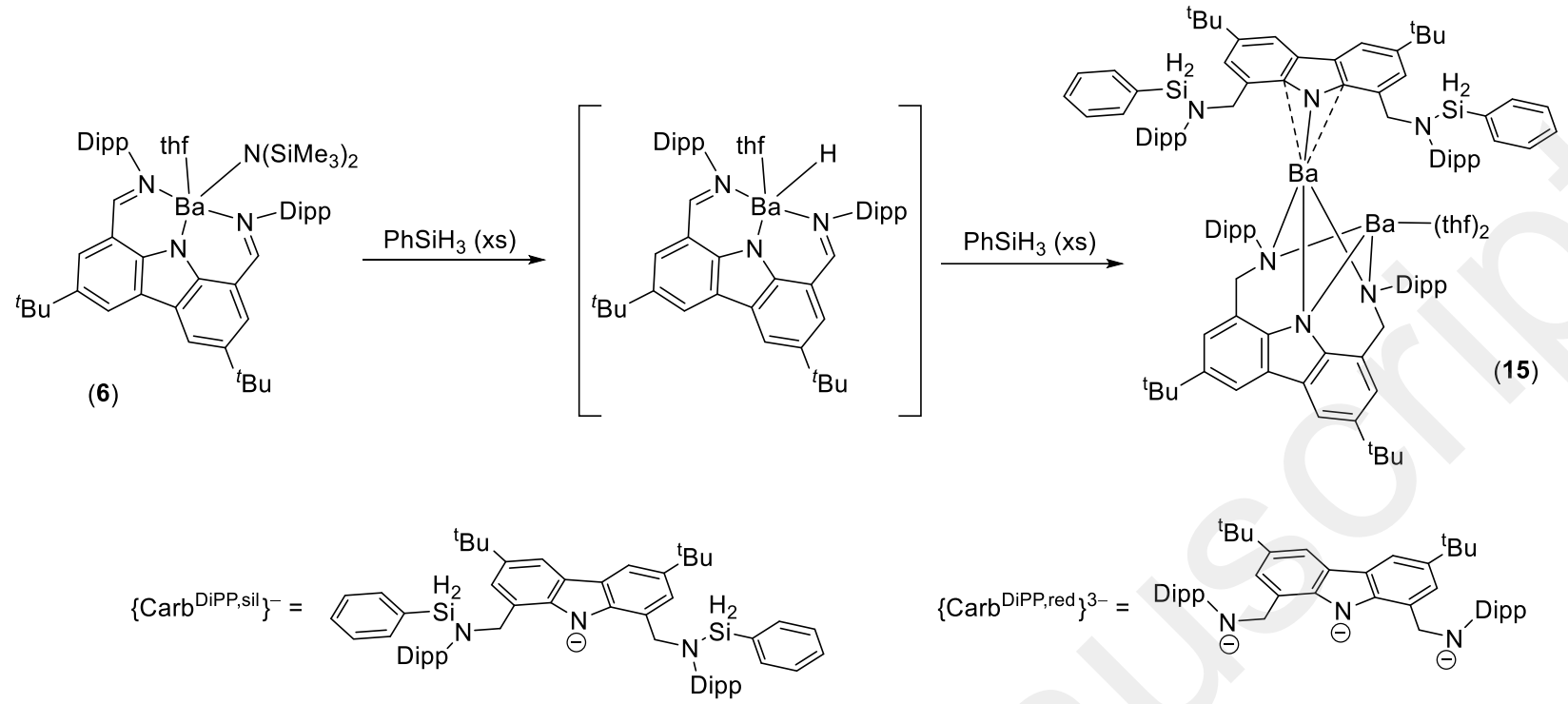

Scheme 2. Formation of $\left[\mathrm{Ba}_{2}\left\{\mathrm{Carb}^{\mathrm{DiPP}, \text { red }}\right\}\left\{\mathrm{Carb}^{\mathrm{DiPP}, \text { silyl }}\right\} \cdot(\text { thf })_{2}\right](\mathbf{1 5})$.

The identity of $\mathbf{1 5}$ was unambiguously established by XRD analysis; on the other hand, the complicated NMR data subsequently recorded in toluene- $d_{8}$ could not be matched with full certainty to the proposed formulation (see Fig. S30). Evidently, the imines in $\left\{\mathrm{Carb}^{\mathrm{DiPP}}\right\}^{-}$are prone to nucleophilic attack by a putative Ba-hydride species, and two of them have been reduced to amides in 15. On the other hand, it appears that the other two original imine groups have been subjected to a process akin to hydrosilylation, thus yielding two $-\mathrm{CH}_{2} \mathrm{~N}(\mathrm{DiPP}) \mathrm{SiH}_{2} \mathrm{Ph}$ moieties. Although the sequence of elementary steps leading to the formation of 15 remains unclear, it seems reasonable to hypothesise that the complex results from self-promoted degradation of the initially targeted "[Carb $\left.\left.{ }^{\text {DiPP }}\right\} \mathrm{BaH} \cdot(\text { thf })_{\mathrm{x}}\right]$ " through a succession of hydride-mediated reduction of imines and hydrosilylation. To support this latter assumption, we note that Ae-hydrides have recently been shown to act as excellent catalysts for imine hydrosilylation. ${ }^{65}$ Although it is reproducible, the synthesis of $\mathbf{1 5}$ was not further investigated nor optimised. 


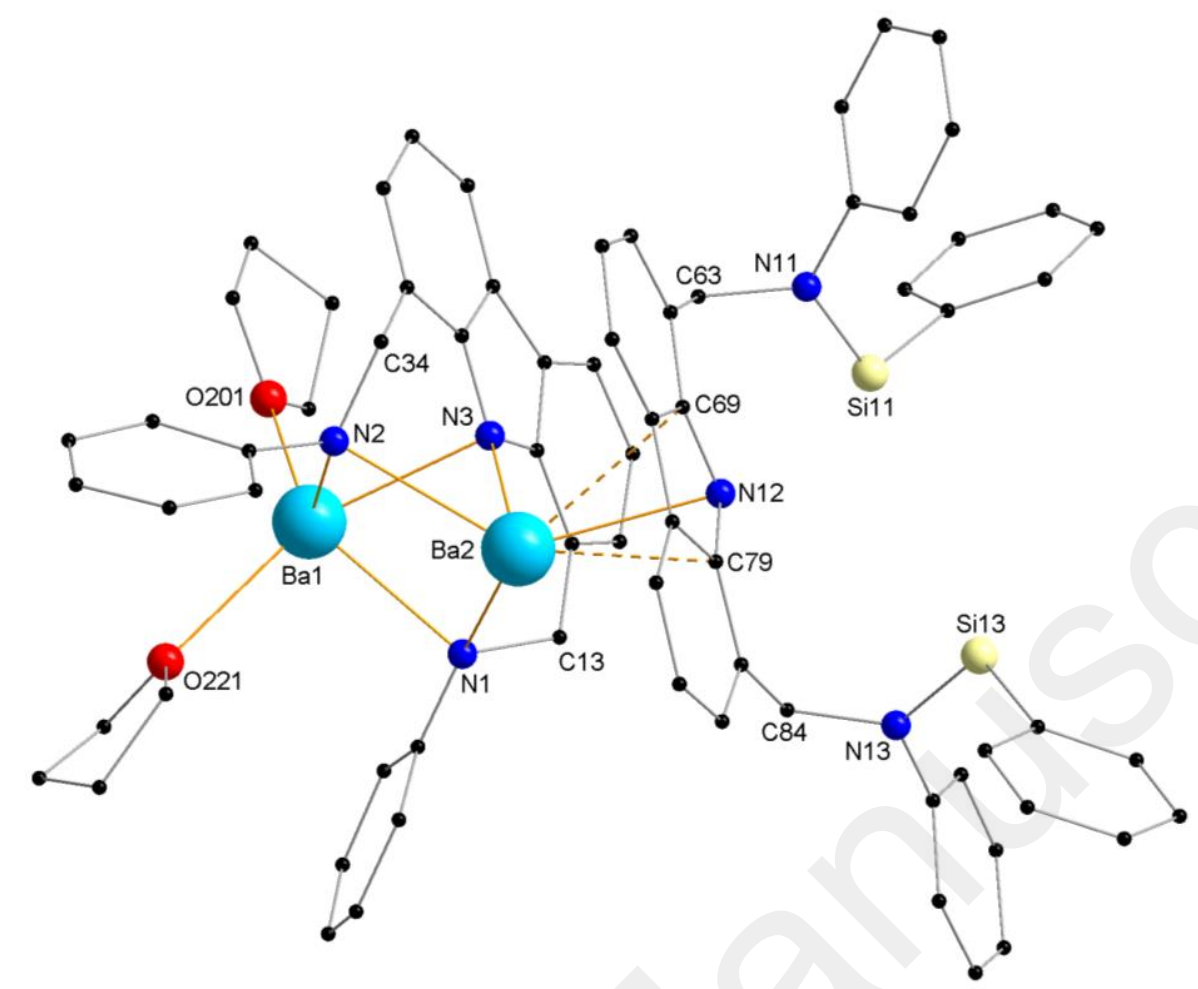

Figure 12. Representation of the molecular solid-state structure of $\left[\mathrm{Ba}_{2}\left\{\mathrm{Carb}^{\mathrm{DiPP}, \text { red }}\right\}\left\{\mathrm{Carb}^{\mathrm{DiPP}, \text { silyl }}\right\} \cdot(\text { thf })_{2}\right](\mathbf{1 5})$. $\mathrm{H}$ atoms, ${ }^{\mathrm{i}} \mathrm{Pr}$ and ${ }^{\mathrm{t}} \mathrm{Bu}$ groups omitted for clarity. Selected interatomic distances $(\AA)$ : Ba1-N1 = 2.714(3), Ba1-N2 = 2.706(4), Ba1-N3 = 2.709(3), Ba1-O201 = 2.731(3), Ba1-O221 = 2.761(4), Ba2-N1 = 2.815(4), Ba2-N2 = 2.857(3), $\mathrm{Ba} 2-\mathrm{N} 3=2.627(3), \mathrm{Ba} 2-\mathrm{N} 12=2.826(3), \mathrm{Ba} 2-\mathrm{C} 69=3.042(4), \mathrm{Ba} 2-\mathrm{C} 79=2.969(4), \mathrm{N} 1-\mathrm{C} 13=1.479(5), \mathrm{N} 2-\mathrm{C} 34=$ $1.483(5), \mathrm{N} 11-\mathrm{C} 63=1.476(5), \mathrm{N} 13-\mathrm{C} 84=1.474(5)$.

The molecular structure of $\mathbf{1 5}$ features two inequivalent barium atoms (Fig. 12). Ba1 is five-coordinate, with a coordination sphere made of three Ba-N bonds in the range 2.706(4)-2.714(3) $\AA$ and completed by the presence of two thf molecules at distances of 2.731(3) and 2.761(4) $\AA$. The atom Ba2 is four-coordinate, with interatomic distances to the nitrogen atoms N1, N2, N3 and N12 between 2.627(3) and 2.857(3) A. There are therefore considerable differences in the Ba-N interatomic distances in this bimetallic complex. In addition, $\mathrm{Ba} 2$ is involved in two $\mathrm{C}(\pi)$-interactions with $\mathrm{C} 69$ and $\mathrm{C} 79$, with short $\mathrm{Ba} 2-\mathrm{C} 69$ and $\mathrm{Ba} 2-\mathrm{C} 79$ distances of 3.042(4) and 2.969(4) $\AA$, resulting in $\eta^{3}$ bonding with the carbazolate core. The N1-C13, N2C34, N11-C63 and N13-C84 bond lengths, in the range 1.474(5)-1.483(5), are all consistent with single C$\mathrm{N}$ bond character and, thus, $s p^{3}$-hybridised nitrogen and carbon atoms. Accordingly, the final refinement indicates that each of the atoms C13, C34, C63 and C84 are each bound to two $\mathrm{H}$ atoms, although their positions were idealised and not located from the Fourier difference map. Both ${ }^{1} \mathrm{H}$ and ${ }^{13} \mathrm{C}\left\{{ }^{1} \mathrm{H}\right\}$ NMR data confirmed the absence of imine groups in $\mathbf{1 5}$. This is seen as the result of imine reduction upon addition of a hydride at C13 and C34, or formal hydrosilylation in the case of the imine moieties corresponding N11C63 and N13-C84. Note that the nitrogen atoms N11 and N13 of the (now) silazane functional groups do not interact with the metal centres. 
In a similar attempt to generate a putative "[Carb $\left.\left.{ }^{\text {DiPP }}\right\} \mathrm{CaH} \cdot(\text { thf })_{x}\right]$ " complex, with the hope that the pertaining $\mathrm{Ca}-\mathrm{H}$ hydride would be less prone to unwanted reactivity due to the lower ionic nature of this bond with respect to the Ba-H equivalent, the calcium complex $\left[\left\{\mathrm{Carb}^{\mathrm{DiPP}}\right\} \mathrm{CaN}\left(\mathrm{SiMe}_{3}\right)_{2}\right](\mathbf{1 3})$ was reacted with $\mathrm{PhSiH}_{3}$. Yet, instead of the sought complex, yellow crystals of the centro-symmetric tetranuclear dihydride $\left[\mathrm{Ca}_{4}\left\{\mathrm{Carb}^{\text {DiPP red }}\right\}_{2} \mathrm{H}_{2} \cdot(\text { thf })_{2}\right]$ (16) were reproducibly isolated upon direct recrystallisation from the reaction mixture (Fig. 13).

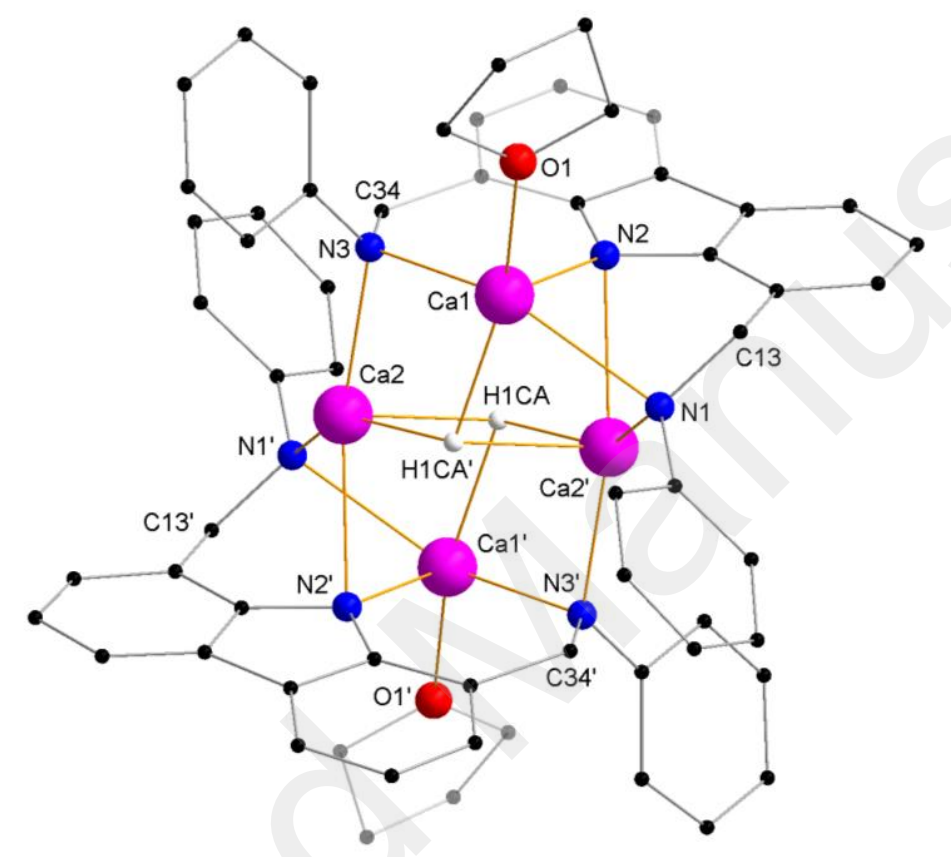

Figure 13. Representation of the molecular solid-state structure of $\left[\mathrm{Ca}_{4}\left\{\mathrm{Carb}^{\mathrm{DiPP}, \text { red }}\right\}_{2} \mathrm{H}_{2} \cdot(\text { thf })_{2}\right](\mathbf{1 6})$. $\mathrm{H}$ atoms other than hydrides, ${ }^{\mathrm{P}} \mathrm{Pr}$ and $\mathrm{B}$ Bu groups omitted for clarity. Metric parameters not given due to the limited quality of data set and refinement $\left(R_{\text {int }}=0.2440, R_{1}=11.80\right)$.

Although the quality of the data set and final refinement are insufficient to warrant a discussion of the metric parameters in this structure $\left(R_{\text {int }}=0.2440, R_{1}=11.80\right)$, there is no ambiguity as to the atom connectivity. There are two very distinct calcium environments, but where both $\mathrm{Ca} 1$ and $\mathrm{Ca} 2$ are five-coordinate. Reduction from $\left\{\mathrm{Carb}^{\text {DiPP }}\right\}^{-}$to $\left\{\mathrm{Carb}^{\text {DiPP,red }}\right\}^{3-}$ is clear upon examination of the N1-C13 and N3-C34 fragments. Most importantly, the presence of bridging hydrides seems unequivocal; their positions correspond to electronic density in the Fourier difference map (although the inaccuracy of the data is high) and is required to ensure charge balance in the tetranuclear edifice. No silicon atom was detected in the structure of 16. Unfortunately, despite our repeated attempts, we were not able to record satisfactory NMR data for this complex. It is possible that a barium complex akin to of $\mathbf{1 6}$ is an intermediate en route towards the formation of 15. Several mechanistic scenarios are conceivable, but in the absence of further experimental data, we are refraining from making unsubstantiated claims about what are likely to be multi- 
step mechanisms. At this stage, the amalgamated data agree with the formation of Ae-hydrides supported by the $\{\mathrm{Carb}\}^{-}$ligand; yet, the imine groups in the ligand backbone appear to be exceedingly sensitive towards the high reactivity of these compounds and are further derivatised during so far uncontrollable processes.

Finally, the calcium-stannyl $\left[\left\{\mathrm{Carb}^{\mathrm{DiPP}}\right\} \mathrm{CaSn}\left(\mathrm{SiMe}_{3}\right)_{3} \cdot\right.$ thf $](\mathbf{1 7})$, that is, the direct analogue of the barium complex $\left[\left\{\mathrm{Carb}^{\mathrm{DiPP}}\right\} \mathrm{BaSn}\left(\mathrm{SiMe}_{3}\right)_{3} \cdot \mathrm{thf}\right](\mathbf{5}),{ }^{42}$ was successfully isolated in $39 \%$ yield from the reaction of 11 with in situ-prepared [ $\mathrm{KSn}\left(\mathrm{SiMe}_{3}\right)_{3} \cdot \mathrm{thf}_{\mathrm{n}}$ ]. Examples of known Ca-stannyls are confined to the seminal $\left[\mathrm{Ca}\left(\mathrm{SnMe}_{3}\right)_{2} \cdot(\text { thf })_{4}\right]^{66}$ and to the much more recent $\left[\left\{\mathrm{BDI}^{\mathrm{DiPP}}\right\} \mathrm{Ca}-\left(\mu_{2}-\mathrm{H}\right)-\left(\mathrm{SnPh}_{3}\right) \mathrm{Ca}\left\{\mathrm{BDI}^{\mathrm{DiPP}}\right\}\right]$ and $\left[\left\{\mathrm{BDI}^{\mathrm{DiPP}}\right\} \mathrm{Ca}\left(\mathrm{SnPh}_{3}\right)\right]_{2} \cdot{ }^{67}$ The ${ }^{1} \mathrm{H}$ NMR spectrum of $\mathbf{1 7}$ is slightly different from the barium congener $\mathbf{5}$, in which the ${ }^{i}$ Pr groups are fluxional at room temperature. Complex 17 shows 4 different ${ }^{i} \operatorname{Pr}$ environments, indicating a lack of free rotation of the two DiPP groups; this is unsurprising considering the more sterically saturated coordination sphere of Ca compared to Ba. In the ${ }^{1} \mathrm{H}$ NMR spectrum, the methyl resonance of the $\mathrm{Sn}\left(\mathrm{SiMe}_{3}\right)_{3}$ fragment at $0.30 \mathrm{ppm}$ shows scalar $\mathrm{H}-\mathrm{Sn}$ coupling constant $\left({ }^{3} J_{1 \mathrm{H}-\mathrm{Sn}}=10.7 \mathrm{~Hz}\right)$, similar to that of $5\left({ }^{3} J_{1 \mathrm{H}-\mathrm{Sn}}=10.6 \mathrm{~Hz}\right)$. The ${ }^{29} \mathrm{Si}\left\{{ }^{1} \mathrm{H}\right\}$ INEPT spectrum displays a sharp singlet at $-12.5 \mathrm{ppm}$ with clearly visible tin satellites and pertaining coupling constants $\left({ }^{1} J_{29 \mathrm{Si}-119 \mathrm{Sn}}=27.1 \mathrm{~Hz},{ }^{1} J_{29 \mathrm{Si}-117 \mathrm{Sn}}=26.0 \mathrm{~Hz}\right) \mathrm{much}$ smaller than those in $\mathbf{5}\left({ }^{1} J_{\mathrm{Si}-119 \mathrm{Sn}}=83.5 \mathrm{~Hz},{ }^{1} J_{\mathrm{Si}-117 \mathrm{Sn}}=73.1 \mathrm{~Hz}^{42}\right)$. The molecular solid-state structure features the calcium atom $\mathrm{Ca} 1$ at the centre of a distorted square pyramidal arrangement $\left(\tau_{5}=0.31\right)$, where the $\mathrm{N}_{\text {imine }}$ and tin atoms N1, N3 and Sn1 occupy the equatorial positions (Fig. 14). The Ca- $\mathrm{N}_{\text {carbazolate }}$ and Ca- $\mathrm{N}_{\text {imines }}$ interatomic distances are similar to those measured in the other calcium complexes 11-13, although some small variations are observed (see Table 1). The Ca1-Sn1 bond length in 17, 3.2564(7) $\AA$, is commensurate with those in $\left[\left\{\mathrm{BDI}^{\mathrm{DiPP}}\right\} \mathrm{Ca}-\mu_{2}-\mathrm{H}-\left(\mathrm{SnPh}_{3}\right) \mathrm{Ca}\left\{\mathrm{BDI}^{\mathrm{DiPP}}\right\}\right]$ and $\left[\left\{\mathrm{BDI}^{\mathrm{DiPP}}\right\} \mathrm{Ca}\left(\mathrm{SnPh}_{3}\right)\right]_{2}, 3.2137(4)$ and 3.3221(5), although the $\mathrm{Ca}$ atoms are four-coordinate in these complexes.$^{67}$ It also compares well with that in the six-coordinate $\left[\mathrm{Ca}\left(\mathrm{SnMe}_{3}\right)_{2} \cdot(\text { thf })_{4}\right](3.2721(3) \AA) .{ }^{66}$ Evidently, the coordination number around calcium influences little the Ca-Sn interatomic distances; this is thought to reflect the nature of the bond between the two metals, which DFT computations have shown to be highly ionic and polarised $\left({ }^{\delta+} \mathrm{Ca} \cdots \mathrm{Sn}^{\delta-}\right.$ ), with only a small covalent contribution. ${ }^{42,67} \mathrm{The}^{\mathrm{Si}} \mathrm{i}_{\mathrm{i}} \mathrm{Sn}-\mathrm{Si}_{\mathrm{j}}$ angles around the tin atom range between 94.56(4)-100.51(4) ${ }^{\circ}$, as would be expected for a tin(II) centre with little hybridisation between $s$ and $p$ orbitals. 


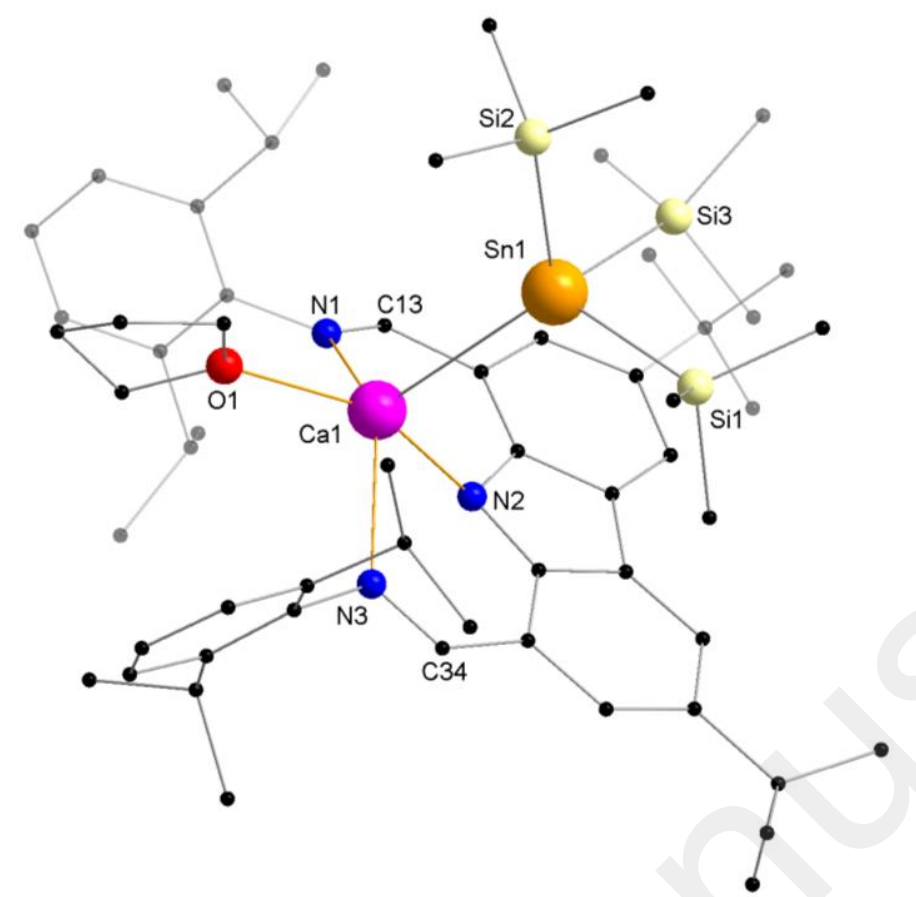

Figure 14. Representation of the molecular solid-state structure of $\left[\left\{\mathrm{Carb}^{\mathrm{DiPP}}\right\} \mathrm{CaSn}\left(\mathrm{SiMe}_{3}\right)_{3} \cdot \mathrm{thf}\right](\mathbf{1 7}) . \mathrm{H}$ atoms omitted for clarity. Only the main components of the disordered ${ }^{\mathrm{B} u}$ and ${ }^{\mathrm{i}} \mathrm{Pr}$ groups depicted. Selected interatomic distances $(\AA)$ and angles $\left({ }^{\circ}\right)$ : Ca1-N1 $=2.519(3), \mathrm{Ca} 1-\mathrm{N} 2=2.295(3), \mathrm{Ca} 1-\mathrm{N} 3=2.511(3), \mathrm{Ca} 1-\mathrm{O} 1=2.349(2), \mathrm{Ca} 1-$ $\mathrm{Sn} 1=3.2564(7), \mathrm{Sn} 1-\mathrm{Si} 1=2.6092(12), \mathrm{Sn} 1-\mathrm{Si} 2=2.5781(11), \mathrm{Sn} 1-\mathrm{Si} 3=2.5923(12)$; N1-Ca1-N2 = 77.02(9), N1$\mathrm{Ca} 1-\mathrm{N} 3=134.39(9), \mathrm{N} 1-\mathrm{Ca} 1-\mathrm{O} 1=91.81(9), \mathrm{N} 1-\mathrm{Ca} 1-\mathrm{Sn} 1=114.79(6), \mathrm{N} 2-\mathrm{Ca} 1-\mathrm{N} 3=78.58(9), \mathrm{N} 2-\mathrm{Ca} 1-\mathrm{O} 1=$ 152.79(9), N2-Ca1-Sn1 = 99.14(7), N3-Ca1-O1 = 92.72(9), N3-Ca1-Sn1 = 106.70(7), O1-Ca1-Sn1 = 108.06(6), Ca1Sn1-Si1 = 121.97(3), Ca1-Sn1-Si2 = 126.11(3), Ca1-Sn1-Si3 = 108.07(3), Si1-Sn1-Si2 = 100.51(4), Si1-Sn1-Si3 = 94.56(4), Si2-Sn1-Si3 = 99.01(4).

\section{Concluding remarks}

The bis(imino)carbazole $\left\{\mathrm{Carb}^{\mathrm{DiPP}}\right\} \mathrm{H}$ appears to be a ligand suitable for the preparation of a very large range of alkaline-earth complexes. The new Mg-Ba complexes 6-17 disclosed herein are characterised by coordination numbers of four or five, with geometries that approximate trigonal pyramidal (i.e. highly distorted tetrahedral) and square pyramidal, respectively. A summary of the key structural features is collated in Table 1. Several trends emerge from examination of these data. The $\mathrm{N}_{\text {imine }}-\mathrm{N}_{\text {carbazolate }}-\mathrm{N}^{\prime}$ imine angle increases with the size of the Ae element, so that more room is created to accommodate increasingly large metals. Conversely, the bite angle $\mathrm{N}_{\text {imine }}-\mathrm{Ae}-\mathrm{N}^{\prime}$ imine narrows substantially when the metal becomes bigger, because the hosting of the metal by the bis(imine) claw then gradually becomes more difficult. The further consequence of these distortions is a gradual increase of the distance between the metal and the best average $\mathrm{N}=\mathrm{C}_{\text {iminie }}-\mathrm{C}_{1}-\mathrm{C}_{9 \mathrm{a}}-\mathrm{N}_{\text {carb }}-\mathrm{C}_{8 \mathrm{a}}-\mathrm{C}_{8}-\mathrm{C}^{\prime}{ }_{\text {imine }}=\mathrm{N}$ ' backbone plane, an additional adjustment of the geometrical pattern required to maintain the Ae- $\mathrm{N}_{\text {carbazolate }}$ bond. The Ae- $\mathrm{N}_{\text {carbazolate }}$ interatomic distances raise steadily from $\mathrm{Mg}$ to $\mathrm{Ba}$, but these variations essentially match the increase of the ionic radii of the metals. 
Beyond its utility for barium, demonstrated in our earlier communication through the preparation of complexes 1-5, we have hence shown here that $\left\{\mathrm{Carb}^{\mathrm{DiPP}}\right\} \mathrm{H}$ is a versatile platform that can be implemented to the other large alkaline earths, calcium and strontium, and also to their smaller congener, magnesium. Overall, the preparation of stable Ae complexes has so far been successfully extended to various alkalineearth amides, alkyls, halides, silyls and stannyls. In this respect, and also because it is readily available on large scales within a matter of days, $\left\{\mathrm{Carb}^{\mathrm{DiPP}}\right\} \mathrm{H}$ can be compared in efficiency to the ubiquitous $\beta$ diketimine $\left\{\mathrm{BDI}^{\mathrm{DiPP}}\right\} \mathrm{H}$ that has proved so spectacularly successful with calcium and magnesium. Unlike $\left\{\mathrm{BDI}^{\mathrm{DiPP}}\right\} \mathrm{H}$, the new $\left\{\mathrm{Carb}^{\mathrm{DiPP}}\right\} \mathrm{H}$ has failed so far to deliver isolable "simple" Ae-hydrides, even if the available experimental data (compounds 15 and 16) suggest that these species must be formed at least transiently. We are now modifying the ligand framework in order to take into account the observed fragility of the imine groups and make them less prone to hydride nucleophilic attack and formal hydrosilylation; the outcome of these alterations will be reported elsewhere in due course. On the other hand, $\left\{\mathrm{Carb}^{\mathrm{DiPP}}\right\} \mathrm{H}$ allows for the synthesis of solution-stable barium complexes, something that $\left\{\mathrm{BDI}^{\mathrm{DiPP}}\right\} \mathrm{H}$ could not achieve. We therefore believe that the bis(imino)carbazole is a useful addition to the growing arsenal of tools available to the synthetic organic and organometallic chemists with an interest in alkaline-earth chemistry, and could contribute significantly to the further expansion of Ae-mediated reactivity and molecular catalysis. 
Table 1. Summary of X-ray crystallographic structural data in $\mathrm{Ae}$ complexes 1-17 $(\mathrm{Ae}=\mathrm{Mg}, \mathrm{Ca}, \mathrm{Sr}$ or $\mathrm{Ba})$.

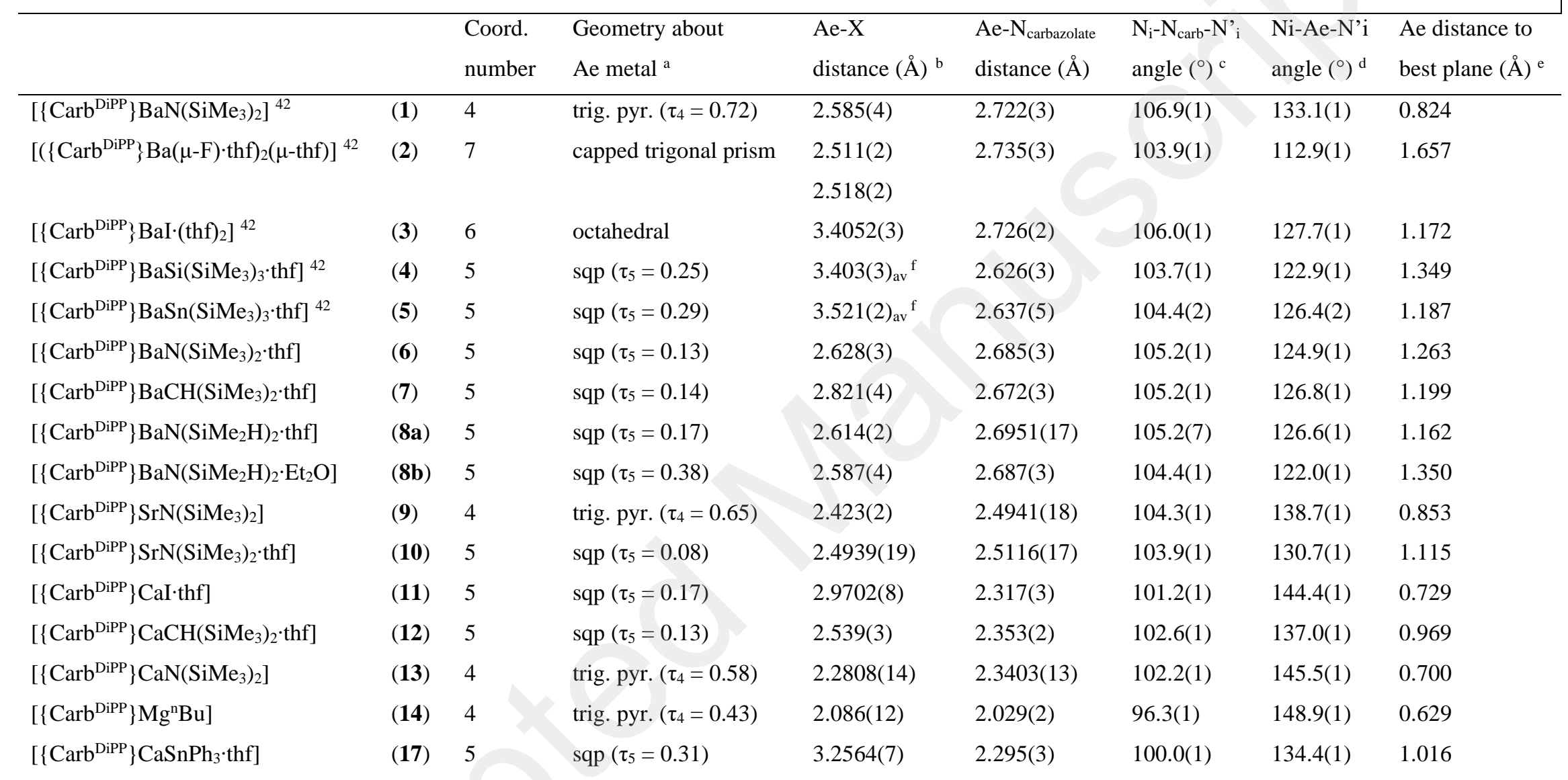

${ }^{\mathrm{a}}$ sqp $=$ square pyramid; trig. pyr. $=$ trigonal pyramid. ${ }^{\mathrm{b}}$ Distance to the metal-bound $\mathrm{N}_{\text {amide }}, \mathrm{C}_{\text {alkyl }}$, halide, $\mathrm{Si}$ or Sn atom. ${ }^{\mathrm{c}} \mathrm{N}_{\text {imine }}-\mathrm{N}_{\text {carbazolate }}-\mathrm{N}^{\prime}$ imine angle. ${ }^{\mathrm{d}} \mathrm{N}_{\text {imine }}-\mathrm{Ae}-$ $\mathrm{N}^{\prime}$ imine angle. ${ }^{\mathrm{e}}$ Distance to the best $\mathrm{N}=\mathrm{C}_{\text {iminie }}-\mathrm{C}_{1}-\mathrm{C}_{9 \mathrm{a}}-\mathrm{N}_{\text {carb }}-\mathrm{C}_{8 \mathrm{a}}-\mathrm{C}_{8}-\mathrm{C}^{\prime}{ }_{\text {imine }}=\mathrm{N}^{\prime}$ backbone plane. ${ }^{\mathrm{f}}$ Averaged over the two occupancy sites. 


\section{Conflicts of interest}

There are no conflicts of interest to declare.

\section{Acknowledgements}

The authors thank the ANR for funding (ANR-17-CE07-0017-01) and for the provision of a PhD studentship to P. M. C.

\section{Notes and references}

1 G. G. Condorelli, G. Malandrino and I. L. Fragalà, Coord. Chem. Rev., 2007, 251, 1931.

2 K. Fromm, Coord. Chem. Rev., 2008, 252, 856.

3 M. Westerhausen, Coord. Chem. Rev., 2008, 252, 1516.

4 M. Westerhausen, Z. Anorg. Allg. Chem., 2009, 635, 13

5 S. Harder, Chem. Rev., 2010, 110, 3852.

6 A. G. M. Barrett, M. R. Crimmin, M. S. Hill and P. A. Procopiou, Proc. R. Soc. A, 2010, 466, 927.

7 S. Kobayashi and Y. Yamashita, Acc. Chem. Res., 2011, 44, 58.

8 A. Torvisco, A. Y. O’Brien and K. Ruhlandt-Senge, Coord. Chem. Rev., 2011, 255, 1268.

9 M. Westerhausen, S. Krieck, J. Langer, T. M.A. Al-Shboul and H. Görls, Coord. Chem. Rev., 2013, 257, 1049 .

10 Alkaline-Earth Metal Compounds: Oddities and Applications, Topics in Organometallic Chemistry, ed. S. Harder, Springer-Verlag Berlin, 2013.

11 M. S. Hill, D. J. Liptrot and C. Weetman, Chem. Soc. Rev., 2016, 45, 972.

12 M. Westerhausen, A. Koch, H. Görls and S. Krieck, Chem. Eur. J., 2017, 23, 1456.

13 D. Mukherjee, D. Schuhknecht and J. Okuda, Angew. Chem. Int. Ed., 2018, 57, 9590.

14 K. M. Fromm, Coord. Chem. Rev., 2020, 408, 213193.

15 Early Main Group Metal Catalysis: Concepts and Reactions, ed. S. Harder, Wiley-VCH Verlag GmbH \& Co, 2020.

16 P. M. Chapple and Y. Sarazin, Eur. J. Inorg. Chem., DOI: 10.1002/ejic.202000501.

17 J. Spielmann, G. Jansen, H. Bandmann and S. Harder, Angew. Chem. Int. Ed., 2008, 47, 6290.

18 J. Spielmann and S. Harder, J. Am. Chem. Soc., 2009, 131, 5064.

19 D. J. Liptrot, M. Arrowsmith, A. L. Colebatch, T. J. Hadlington, M. S. Hill, G. Kociok-Köhn and M. F. Mahon, Angew. Chem. Int. Ed., 2015, 54, 15280.

20 M. D. Anker, C. E. Kefalidis, Y. Yang, J. Fang, M. S. Hill, M. F. Mahon and L. Maron, J. Am. Chem. Soc., 2017, 139, 10036 
21 A. S. S. Wilson, M. S. Hill, M. F. Mahon, C. Dinoi and L. Maron, Science, 2017, 358, 1168.

22 A. Causero, H. Elsen, J. Pahl and S. Harder, Angew. Chem. Int. Ed., 2017, 56, 6906.

23 S. Brand, H. Elsen, J. Langer, W. A. Donaubauer, F. Hampel and S. Harder, Angew. Chem. Int. Ed., 2018, 57, 14169.

24 A. S. S. Wilson, C. Dinoi, M. S. Hill, M. F. Mahon and L. Maron, Angew. Chem. Int. Ed., 2018, 57, 15500.

25 B. Rösch, T. X. Gentner, H. Elsen, C. A. Fischer, J. Langer, M. Wiesinger and S. Harder, Angew. Chem. Int. Ed., 2019, 58, 5396.

26 A. S. S. Wilson, C. Dinoi, M. S. Hill, M. F. Mahon, L. Maron and E. Richards, Angew. Chem. Int. Ed., 2020, 59, 1232.

27 S. P. Sarish, S. Nembenna, S. Nagendran and H. W. Roesky, Acc. Chem. Res., 2011, 44, 157.

28 Y. Sarazin and J.-F. Carpentier, Chem. Rec., 2016, 16, 2482.

29 S. Harder, Organometallics, 2002, 21, 3782.

30 M. H. Chisholm, J. Gallucci and K. Phomphrai, Chem. Commun., 2003, 48.

31 A. G. Avent, M. R. Crimmin, M. S. Hill and P. B. Hitchcock, Dalton Trans., 2005, 278.

32 S. Datta, M. T. Gamer and P. W. Roesky, Organometallics, 2008, 27, 1207.

33 T. X. Gentner, B. Rösch, K. Thum, J. Langer, G. Ballmann, J. Pahl, W. A. Donaubauer, F. Hampel and S. Harder, Organometallics, 2019, 38, 2485.

34 P. G. Hayes, G. C. Welch, D. J. H. Emslie, C. L. Noack, W. E. Piers and M. Parvez, Organometallics, 2003, 22, 1577.

35 B. Liu, T. Roisnel, J.-F. Carpentier and Y. Sarazin, Angew. Chem. Int. Ed., 2012, 51, 4943.

36 E. Le Coz, H. Roueindeji, T. Roisnel, V. Dorcet, J.-F. Carpentier and Y. Sarazin, Dalton Trans., 2019, 48, 9173.

37 G. Ballmann, B. Rösch and S. Harder, Eur. J. Inorg. Chem., 2019, 3683.

38 X. Shi, C. Hou, C. Zhou, Y. Song and J. Cheng, Angew. Chem. Int. Ed., 2017, 56, 16650.

39 X. Shi, G. Qin, Y. Wang, L. Zhao, Z. Liu and J. Cheng, Angew. Chem. Int. Ed., 2019, 58, 4356.

40 Y. Sarazin, D. Roşca, V. Poirier, T. Roisnel, A. Silvestru, L. Maron and J.-F. Carpentier, Organometallics, 2010, 29, 6569.

41 B. Liu, T. Roisnel, J.-P. Guégan, J.-F. Carpentier and Y. Sarazin, Chem. Eur. J., 2012, 18, 6289.

42 P. M. Chapple, S. Kahlal, J. Cartron, T. Roisnel, V. Dorcet, M. Cordier, J.-Y. Saillard, J.-F. Carpentier and Y. Sarazin, Angew. Chem. Int. Ed. 2020, 59, 9120.

43 M. Westerhausen, Inorg. Chem., 1991, 30, 96.

44 M. R. Crimmin, A. G. M. Barrett, M. S. Hill, D. J. MacDougall, M. F. Mahon and P. A. Procopiou, Chem. Eur. J., 2008, 14, 11292. 
45 Note that we have substantially improved the efficiency of the preparation of $\left[\mathrm{Ba}\left\{\mathrm{CH}\left(\mathrm{SiMe}_{3}\right)_{2}\right\}_{2} \cdot(\mathrm{thf})_{2}\right]$ compared to the initial report, see the Supporting Information for details. In particular, it is of paramount importance to ensure that the reagent $\left[\mathrm{K}\left\{\mathrm{CH}\left(\mathrm{SiMe}_{3}\right)_{2}\right\}_{2} \cdot \mathrm{thf}\right]$, prepared from $\left(\mathrm{Me}_{3} \mathrm{Si}\right)_{2} \mathrm{CHCl}$, ${ }^{\mathrm{n}} \mathrm{BuLi}$ and ${ }^{\mathrm{t}} \mathrm{BuOK}$, is free of lithium.

CSD database version 5.41, November 2019.

47 S.-O. Hauber, F. Lissner, G. B. Deacon and M. Niemeyer, Angew. Chem. Int. Ed., 2005, 44, 5871.

48 B. Liu, T. Roisnel, J.-F. Carpentier and Y. Sarazin, Chem. Eur. J., 2013, 19, 13445.

49 L. J. Procopio, P. J. Carroll and D. H. Berry, J. Am. Chem. Soc., 1994, 116, 177.

50 W. Hieringer, J. Eppinger, R. Anwander and W. A. Herrmann, J. Am. Chem. Soc., 2000, 122, 11983.

51 O. Michel, K. W. Törnroos, C. Maichle-Mössmer and R. Anwander, Chem. Eur. J., 2011, 17, 4964.

52 A. W. Addison, T. N. Rao, J. Reedijk, J. van Rijn and G. C. Verschoor, J. Chem. Soc. Dalton Trans., 1984, 1349.

53 C. Bellini, V. Dorcet, J.-F. Carpentier, S. Tobisch and Y. Sarazin, Chem. Eur. J., 2016, $22,4564$.

54 L. Yang, D. R. Powell and R. P. Houser, Dalton Trans., 2007, 955.

55 S. Sarish, S. Nembenna, S. Nagendran, H. W. Roesky, A. Pal, R. Herbst-Irmer, A. Ringe and J. Magull, Inorg. Chem., 2008, 47, 5971.

56 M. Arrowsmith, A. Heath, M. S. Hill, P. B. Hitchcock and G. Kociok-Köhn, Organometallics, 2009, 28, 4550 .

57 S. Krieck, H. Görls and M. Westerhausen, J. Am. Chem. Soc., 2010, 132, 12492.

58 N. Kuhn, M. Schulten, R. Boese and D. Bläser, J. Organomet. Chem., 1991, 421, 1.

59 D. Mukherjee and J. Okuda, Angew. Chem. Int. Ed., 2018, 57, 1458.

60 S. Harder and J. Brettar, Angew. Chem. Int. Ed., 2006, 45, 3474.

61 D. Mukherjee, D. Schuhknecht and J. Okuda, Angew. Chem. Int. Ed., 2018, 57, 9590.

62 B. Maitland, M. Wiesinger, J. Langer, G. Ballmann, J. Pahl, H. Elsen, C. Färber and S. Harder, Angew. Chem. Int. Ed., 2017, 56, 11880.

63 D. Mukherjee, T. Höllerhage, V. Leich, T. P. Spaniol, U. Englert, L. Maron and J. Okuda, J. Am. Chem. Soc., 2018, 140, 3403.

64 M. Wiesinger, B. Maitland, C. Färber, G. Ballmann, C. Fischer, H. Elsen and S. Harder, Angew. Chem. Int. Ed., 2017, 56, 16654.

65 H. Elsen, C. Fischer, C. Knepfer, A. Escalona and S. Harder, Chem. Eur. J., 2019, 25, 16141.

66 M. Westerhausen, Angew. Chem. Int. Ed. Engl., 1994, 33, 1493.

67 L. J. Morris, M. S. Hill, I. Manners, C. L. McMullin, M. F. Mahon and N. A. Rajabia, Chem. Commun., 2019, 55, 12964. 